\title{
L-Arginine in Nutrition: Multiple Beneficial Effects in the Etiopathology of Diabetes
}

\author{
Ana Stancic ${ }^{1}$, Aleksandra Korac ${ }^{2}$, Biljana Buzadzic ${ }^{1}$, Vesna Otasevic ${ }^{1}$, \\ Aleksandra Jankovic ${ }^{1}$, Milica Vucetic ${ }^{1}$ and Bato Korac ${ }^{1,}$
}

${ }^{1}$ University of Belgrade, Institute for Biological Research "Sinisa Stankovic", Department of Physiology, Bulevar Despota Stefana 142, 11060 Belgrade, Serbia

${ }^{2}$ University of Belgrade, Faculty of Biology, Institute of Zoology and Center for Electron Microscopy, Studentski trg 16, 11000 Belgrade, Serbia

\begin{abstract}
L-arginine is a nutritionally important amino acid that controls a wide spectrum of cellular functions and physiological processes, acting by itself or through its various metabolites. There are several factors that determine overall L-arginine homeostasis: dietary supplementation, endogenous de novo synthesis, whole-body protein turnover and its extensive metabolism. The destiny of L-arginine is determined by the complex network of enzymes and pathways differentially expressed according to health and disease status. Diabetes is characterized by reduced concentrations of L-arginine in plasma and many tissues, and failure of its metabolic effects. Emerging data suggest that oral supplementation of L-arginine exerts multiple beneficial effects on the complex etiological and pathophysiological basis of diabetes including: i) $\beta$-cell function and mass and ii) obesity and peripheral insulin resistance. This review emphasizes important aspects of L-arginine action which classifies this amino acid as a promising therapeutic approach in the treatment of diabetes.
\end{abstract}

Keywords: L-arginine, diabetes, $\beta$-cells, insulin resistance, obesity.

\section{INTRODUCTION}

Research into L-arginine has a rich history, and started with its isolation from lupin seedlings in 1886 [1], through the clarification of its metabolic pathways as well as nutritional needs, to the discovery that this amino acid is a precursor for nitric oxide (NO) [2], and the recognition of $\mathrm{NO}$ as an endothelium-derived relaxing factor [3, 4]. Due to the 100-year long physiological and nutritional studies on L-arginine, today we are aware that this amino acid is involved in multiple areas of human physiology and metabolism.

The availability of L-arginine for physiological functions is determined by its endogenous sources, including its de novo synthesis and whole-body protein turnover, and its exogenous source, i.e. dietary intake. With respect to endogenous sources, whole-body protein turnover is the main contributor, while de novo synthesis accounts for only $5-15 \%$ of endogenous arginine flux in adult animals and humans [5]. Interestingly, arginine biosynthetic pathways do not have the capacity to compensate for depletion or inadequate dietary supply in adult rats and humans to meet metabolic demand [6-8]. Thus, with regard to dietary requirements, L-arginine is classified as a

*Address corresponding to this author at the University of Belgrade, Institute for Biological Research "Sinisa Stankovic", Department of Physiology, Bulevar despota Stefana 142, 11060 Belgrade, Serbia; Tel: (381-11)-2078-307; Fax: (381-11)-2761-433; E-mail: koracb@ibiss.bg.ac.rs semi-essential or conditionally essential amino acid [9, 10]. Dietary intake of L-arginine remains the primary determinant of plasma arginine levels and may be of special importance in L-arginine homeostasis disturbances.

Diabetes is a complex metabolic disorder caused by a defect in insulin secretion and/or insulin action. Diabetes is associated with disturbances in the metabolism of the main energetic substrates, glucose and lipid. In addition, disturbances in protein and Larginine metabolism [11] result in reduced concentrations of L-arginine in plasma and in many tissues [12]. Such changes in L-arginine homeostasis can be improved by L-arginine supplementation which has been shown to increase plasma urea and protein [13] as well as arginine levels [14] in diabetes. Many of the positive effects of arginine in diabetes, obtained from experimental models of diabetes type 1 and type 2 as well as in diabetic patients [15-17], are thought to be mediated by its effects on endothelium-dependent relaxation and vascular disturbances. However, important progress in L-arginine research suggests that this amino acid and its metabolites play a more complex role in the regulation of whole-body energy homeostasis, and thus dietary supplementation of Larginine could have multiple beneficial effects in the treatment of this disease.

In view of the growing evidence regarding the beneficial effects of L-arginine in diabetes, the aim of 
this review is to highlight the effects of L-arginine on: (1) $\beta$-cells function and population in relation to their role in the etiology and progression of diabetes type 1 and type 2 and (2) peripheral insulin sensitivity in terms of insulin resistance and type 2 diabetes-associated obesity.

\section{L-ARGININE HOMEOSTASIS - REGULATORY PATHWAYS}

\subsection{L-Arginine in Dietary Sources: Nutraceutical Aspects}

The relative amounts of L-arginine in various proteins range from $3 \%$ to $15 \%$ [18]. Foods rich in Larginine include seafood, watermelon juice, nuts, seeds, algae, meats, rice, and soy [19-21]. Differing dietary habits between populations may account for differences in L-arginine plasma levels in various parts of the world. It has been reported that about $5 \mathrm{~g}$ of Larginine is ingested each day in the average Western diet [22].

Oral L-arginine supplementation is hampered by its extensive metabolism. In adult humans, pigs and rats about $40 \%$ of dietary L-arginine is degraded by the small intestine [23, 24]. Absorbed L-arginine is transported to the liver where the major portion is utilized by the hepatic urea cycle. The dietary Larginine that passes the liver has multiple metabolic fates determined by a complex network of factors including arginine transporters in plasma and mitochondrial membranes and several key enzymatic pathways differentially expressed according to the cell type, age and developmental stage, diet and health and disease status. Thus, multiple endogenous and exogenous aspects need to be considered when Larginine is used as a nutraceutical agent. To date, the favorable effects of exogenous L-arginine have been documented in many developmental and health problems including male and female infertility, burns and trauma, wound healing, immunomodulation, HIV/AIDS, athletic performance, cancer, gastrointestinal diseases and diabetes [25-30].

Oral supplementation of L-arginine, in appropriate doses and chemical forms, has been reported to be safe in both animals and human. L-arginine shows high stability under sterilized conditions and no toxicity to mammalian cells [10]. Supplementation of L-arginine is recommended at a dose of $9 \mathrm{~g} / \mathrm{day}$, divided into three doses. Such supplementation has several advantages: (1) prevents gastrointestinal discomfort due to the rapid production of a large amount of NO; (2) increases the availability of circulating L-arginine over a longer period of time; and (3) avoids potential imbalance among dietary amino acids [19, 31, 32].

However, it should be noted that L-arginine can exert some side effects when it is supplemented in high, supraphysiological doses [33, 34] and in longterm time period $[35,36]$. Higher oral doses of Larginine- $\mathrm{HCl}$ (>9 g/day) are occasionally associated with nausea, gastrointestinal discomfort, and diarrhea for some subjects [33, 34]. L-arginine supplementation can also induce changes in numerous chemicals and electrolytes in the blood, including potassium [37]. Another possible side effect of L-arginine is anaphylaxis. It has been shown that NO underlies mechanisms that lead to pathogenesis of anaphylactic shock [38] and that L-arginine administration reverses beneficial effects of inhibition of NO production induced by L-arginine analog, $\mathrm{N}^{\mathrm{G}}$-nitro-L-arginine methyl ester (L-NAME) [39, 40].

In addition, there are few pathophysiological states where L-arginine might be applied with caution including myocardial infarction [41], asthma [42, 43], viral infections (i.e. cold sores, genital herpes) [44], cancer $[35,45,46]$, renal failure and liver disease [36, $37,47]$.

In contrast to such undesirable effects of L-arginine when it is administrated in uncontrolled manner, supplementation of this amino acid in appropriate physiological doses, duration and intake frequency shows multiple beneficial effects in various physiological and pathological states.

\subsection{L-Arginine Synthesis}

Although synthesis of arginine from citrulline occur in many cell types [48-50], a major part of de novo synthesis occurs via collaboration between the epithelial cells of the small intestine and proximal tubule cells of the kidney (the "intestinal-renal axis" of arginine synthesis) [9, 23, 51-53]. The cooperation between the small intestine and kidney in the biosynthesis of arginine is derived from developmental changes in the key enzymes involved in arginine synthesis and catabolism. At birth, the small intestine is the major site of net arginine synthesis [54, 55]. Subsequently, intestinal arginase expression increases and enterocytes become the major site of net citrulline production due to high expression of three key regulatory enzymes for its synthesis [55-57]. This transition at the level of small intestine is compensated 
by the gradual increased capacity of the kidney to synthesize arginine from citrulline, extracted from the blood after release from the small intestine. Thus, in adults the kidneys take over the role of about $60 \%$ of net arginine synthesis [6,58]. In contrast, in the liver there is no or little net production of arginine due to high arginase activity in hepatocytes [59]. For details of L-arginine metabolism see Figure $\mathbf{1}$ and the excellent review articles by $\mathrm{Wu}$ and Moriss [5] and $\mathrm{Wu}$ and coworkers [60].

\subsection{L-Arginine Interconversion Pathways}

The importance of L-arginine from the physiological and nutritional aspects arises from the fact that, in addition to L-arginine per se, products of its metabolism play significant roles in the regulation of fundamental cellular processes and physiological functions. Arginine is metabolized through multiple inter-related metabolic pathways that show complex compartmentalization and interactions at the cellular, tissue and systemic levels. Not only is it metabolically interconvertable with the amino acids proline and glutamate, but it also serves as a precursor for the synthesis of protein, NO, creatine, polyamines, agmatine and urea. Key enzymes catalyzing these pathways are arginase, NO synthases (NOSs), arginine:glycine amidinotransferase and arginine decarboxylase.

In mammals, the arginase pathway is quantitatively most important for arginine catabolism. Arginase exists in two distinct forms (type I and type II), encoded by separate genes, that are immunologically distinguishable and have specific subcellular localizations and tissue distribution [61]. Arginase I is a cytosolic enzyme located primarily in the liver of ureotelic organisms where it serves as one of the key enzymes of the urea cycle [59]. Arginase II is located

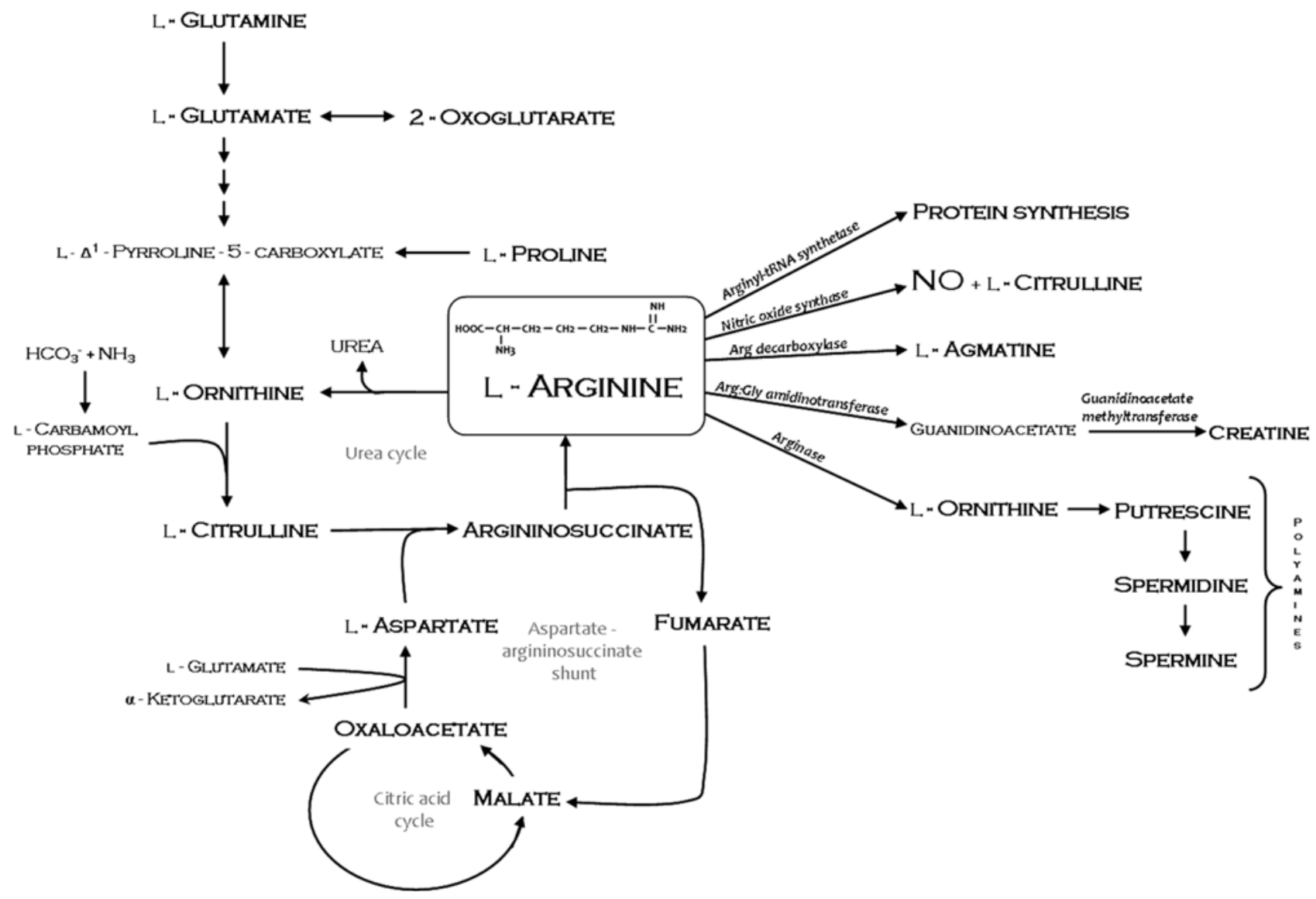

Figure 1: General pathways of L-arginine metabolism. Major players in L-arginine de novo synthesis and catabolism are shown. Central place in the scheme belongs to the Krebs bicycle (consisting of urea cycle, citric acid cycle and aspartateargininosuccinate shunt) that represents meeting point for the majority of L-arginine metabolic pathways, both anabolic and catabolic. L-arginine and its metabolites are highly important in maintaining the structural and functional integrity of cells (especially in the context of cell signaling). Arginase-catalyzed pathway provides the highest rate of L-arginine turnover (to ornithine and, further, to polyamines) but the biological effects of this amino acid are far more visible through its conversion into nitric oxide by enzyme nitric oxide synthase. In the scheme, only enzymes that convert L-arginine into its key metabolites are identified. 
within the mitochondrion and has a widespread tissue distribution, with the highest levels of expression in the kidney, prostate, and brain and lower levels in a variety of other tissues including the pancreas [62-64]. The products of arginase activity are polyamines, putrescine, spermidine and spermine. Polyamines play important roles in the differentiation, growth and proliferation of cells $[65,66]$. They interact with various cell components including nucleic acids, and their intracellular concentration increases in certain cell phases [67].

Furthermore, the significant role of arginase in the regulation of L-arginine metabolic effects may be ascribed to the fact that arginase effectively competes with NOSs for L-arginine [5]. Therefore, it determines the availability of L-arginine for NO synthesis and NOdependent biological processes. In diabetes, increased liver arginase activity causes a decrease in L-arginine plasma level and NO-mediated effects [11].

\subsubsection{NO-Producing System}

Another pathway of arginine metabolism is its oxidation catalyzed by NOS, which leads to NO and citrulline production. The large majority of the physiological effects of exogenous L-arginine is due to its metabolism by NOS, despite the fact that there is a low level of NO production compared to the overall arginine catabolism. The reason for this lies in the chemical nature of NO; as a free radical, NO possesses high reactivity. This classifies $\mathrm{NO}$ as a signaling molecule with significant miscellaneous potential. NO mediates signaling either through cGMPdependent or independent pathways. The former involves activation of soluble guanylate cyclase and cGMP-signaling [68], while the latter comprises NO interactions with various intracellular molecules ranging from small redox molecules (superoxide and glutathione) to large biomolecules (proteins membrane receptors, intracellular kinases and phosphatases and transcriptional factors).

In mammals, three isoforms of NOS have been identified: neuronal (nNOS or NOSI) and endothelial (eNOS or NOSIII), originally described in neuronal tissue and endothelial cells, respectively, and inducible NOS (iNOS and NOSII), originally found in macrophages [69, 70]. All three isoforms identified in mammals are heme-containing proteins that are dimeric in native conditions; dimerization of NOS is supported by L-arginine, suggesting its structural role, in addition to a substrate role for NOS [71]. The initially established paradigm that $\mathrm{nNOS}$ and eNOS are constitutively expressed, while iNOS is solely an inducible form is being challenged by the increasing number of reports demonstrating that all three isoforms can be induced by different stimuli and expressed in various tissues and cells $[69,70]$. However there are clear differences between the NOS isoforms in relation to the level of NO production; iNOS produces higher NO levels $(\mu \mathrm{M}-\mathrm{mM})$ and remains active for a longer time period compared to nNOS and eNOS (level of NO production from $n M-\mu M)$.

The effect of NO depends on its local concentration, which is determined by the rate of its synthesis, and by the cellular redox milieu [69]. It is important to mention that dietary supplementation of arginine increases NO synthesis within the physiological range in various tissues [70]. Besides, the effects of NO depend on the intracellular place of its production. To accomplish both issues, NOSs are tightly regulated at the transcriptional and translational levels, through $\mathrm{co}^{-}$and posttranslational modification, by substrate and cofactors availability and subcellular compartmentalization $[70$, 72]. NO synthases are localized at specific cellular sites, where they are in close proximity to their target molecules. This functional localization is defined by lipid modifications and protein-protein interactions [72]. A perfect example of spatial dependence of NOS function has been demonstrated in $\beta$-cells, where the specific localization of nNOS in secretory vesicles enables this enzyme to control insulin secretion, as it is discussed below [73].

\subsubsection{L-Arginine and NOS: Arginine Paradox}

The intracellular concentration of L-arginine is in the range of $100-800 \mu \mathrm{M}$ in cells and from $40-100 \mu \mathrm{M}$ in plasma [74]. Therefore, it seems that there is saturation level of L-arginine for $\mathrm{NO}$ synthesis since the $\mathrm{Km}$ of Larginine for nNOS is 1.4-2.2 $\mu \mathrm{M}$ and for eNOS is $\sim 2.9$ $\mu \mathrm{M}$ [75]. However, it has been shown that an external supply of L-arginine increases cellular NO production [76]. This phenomenon is known as the "arginine paradox". In other words, this shows that exogenous Larginine application in vivo causes additional NOmediated biological effects despite the fact that NOSs are theoretically saturated with the substrate. Supplementation of L-arginine has been shown repeatedly to exert beneficial effects on endotheliumdependent vasodilatation in vivo in a dose-dependent manner [77]. This phenomenon remains to be explained, but may be related to endogenous NOS inhibitors [75], receptor-mediated activation of NOS by 
exogenous L-arginine [78] and compartmentalization of intracellular L-arginine $[79,80]$.

\section{BENEFICIAL EFFECTS OF L-ARGININE IN DIABETES}

\section{1. $\beta$-Cells in Diabetes}

Diabetes is the result of an inadequate mass of functional $\beta$-cells. In type 1 diabetes, the immune system attacks and destroys $\beta$-cells by mechanisms still incompletely understood [81]. Type 2 diabetes is a progressive disorder which begins with peripheral insulin resistance and ends with the failure of pancreatic $\beta$-cells. To compensate for peripheral insulin resistance, pancreatic $\beta$-cells increase in mass and secrete more insulin, leading to hyperinsulinemia. However, at a certain point, $\beta$-cells can no longer compensate for peripheral insulin resistance, and plasma glucose levels rise. Increased glucose levels, along with increased levels of free fatty acids due to insulin resistance, can damage $\beta$-cells (gluco- and lipotoxicity), leading to progressive loss of these cells [82]. Thus, it seems likely that the replacement of $\beta$-cells could allow physiological control of glycemia in both types of the disease. Human islets transplantation is successful in restoring normal glycemia, but it is limited by the need for toxic immunosuppressive drugs, the scarcity of donors, and graft failure usually within a few years [83]. Alternative ways of replacing $\beta$-cells are needed and may theoretically be obtained by: (a) replication of the remaining $\beta$-cells; (b) neogenesis and (c) transplantation of $\beta$-cells derived from stem or somatic precursor cells. In adults, the capacity of highly differentiated $\beta$-cells to replicate is very low $[84,85]$. Thus, neogenesis represents an attractive approach to restore functional $\beta$-cell population from non-insulin progenitor cells in the pancreas occurring in two phases, extensive proliferation of the precursor cells followed by their differentiation [85]. The source of new $\beta$-cells may be the pancreas itself (acinar, ductal and endocrine cells) or extra-pancreatic tissue such as the liver. Understanding the molecular mechanisms that trigger and control neogenesis as well as the nature of precursor cells has been the focus of diabetes research in the last decade and is central in the therapeutic approaches to induce meaningful $\beta$-cell neogenesis in diabetes.

\subsubsection{L-Arginine Induces $\beta$-Cell Regeneration}

The $\beta$-cell regenerative capacity of $L$-arginine and the underlying mechanisms of its action in the diabetic pancreas have recently been reported [86]. We reported that 12 days of oral supplementation with Larginine had multiple beneficial roles in the diabetic pancreas resulting in endocrine pancreatic cell neogenesis (Figure 2). Initially, this included activation of pancreatic duodenum homeobox-1 (PDX-1), a specific transcription factor that determines $\beta$-cell phenotype including the expression of insulin, glucose transporter 2 (GLUT2) and hexokinase IV [87]. Strong coexpression of PDX-1 with insulin was observed in exocrine pancreas suggesting that precursors of new $\beta$-cells reside here. Surprising plasticity and capacity of differentiated acinar and ductal cells to transdifferentiate in insulin-producing cells has been shown previously under various conditions when the endocrine function of this gland was challenged [8890]. Our results suggest that L-arginine could be one of the stimuli that induce the transition of exocrine cells into endocrine $\beta$-cells in the diabetic pancreas [86]. This process appears to involve proliferation of the exocrine cells, since L-arginine induces nuclear translocation of proliferating cell nuclear antigen (PCNA), positive regulators of cell growth and proliferation as well as nuclear factor-kB (NF-kB), a ubiquitous transcription factor, whose specific function in the pancreas is activation of transcription in so-called "regenerative" genes [91, 92]. It seems likely that the observed effects of L-arginine on $\beta$-cell regeneration are NO-dependent as strong nNOS expression was observed after L-arginine treatment in diabetic animals. This suggests that nNOS-derived NO plays a more complex role in the regulation of $\beta$-cell population dynamics in addition to its role in the regulation of insulin secretion (discussed below).

A similar beneficial effect of the L-arginine/NO pathway in the pancreas was recently reported after an L-arginine rich diet in rats with type 1 diabetes [93]. Namely, coconut kernel protein, which is rich in Larginine, reduced diabetes-related pancreatic damage, in parallel with an increase in plasma NOS activity.

There is also experimental evidence that L-arginine causes an increase of polyamines levels in the diabetic pancreas suggesting that the effects of L-arginine in recovery of the $\beta$-cell population may be NOindependent $[94,95]$.

\subsubsection{L-Arginine Regulates $\beta$-Cell Metabolism and Insulin Secretion}

In addition to restoring $\beta$-cell mass, the beneficial effects of L-arginine on these cells could be due to its interference with insulin synthetic and secreting 

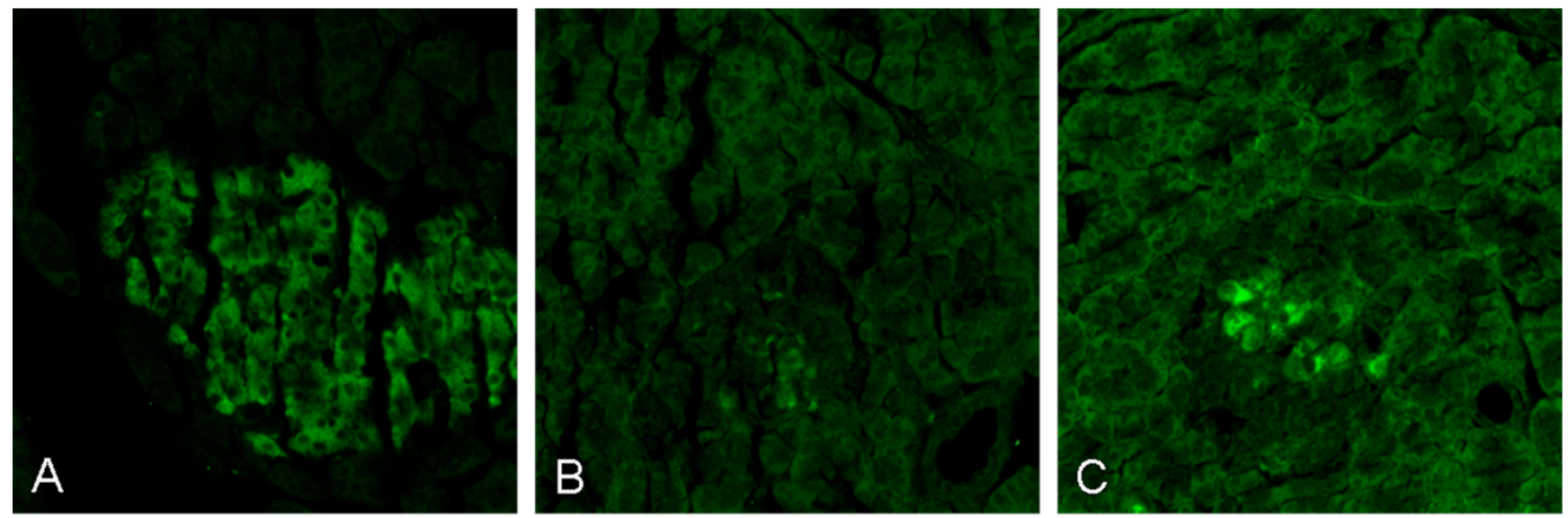

Figure 2: L-arginine restores population of insulin secreting cells in diabetes. Insulin immunofluorescence in pancreas of control $(\mathbf{A})$, diabetic $(\mathbf{B})$ and L-arginine-treated diabetic (C) rats. Pancreatic sections were labeled with anti-insulin, and fluorescence was analyzed by confocal microscope. Magnification: x 40, orig. Reproduced from Vasilijević et al. (2007) with permission from The Journal of Physiology.

pathways (Figure 3). The role of L-arginine in the stimulation of insulin secretion has been shown in physiological conditions and in the diabetic state [96, 97]. The effect of L-arginine on insulin secretion is more complex than its action as a cationic amino acid on membrane depolarization [98, 99], but could also be mediated by the products of its metabolism in pancreatic $\beta$-cells.

It has been shown than L-arginine supplementation in diabetic animals increases pancreatic arginase activity and polyamine levels [94]. Polyamines play a role in insulin biosynthesis and $\beta$-cell replication [66]. They are localized in the secretory granules of $\beta$-cells and their concentration increases in response to $\beta$-cell mitogens, such as glucose and growth hormone [66].

The effects of L-arginine on insulin secretion could also be mediated by NO. NO acts as a physiological modulator of islet hormone release through Snitrosylation of certain thiol-dependent enzymes and regulatory proteins involved in the insulin-releasing pathway, as well as derangement of the reduced/oxidized GSH equilibrium [100]. However, many studies in which NOS activity was manipulated by NO donors and NOS substrates produced controversial data regarding the influence of $\mathrm{NO}$ on islet hormone release. Data suggest that L-argininederived NO may mediate insulin secretion via stimulation of guanylate cyclase and cGMP formation [101], while some authors reported inhibitory effects of NO on insulin release [102]. Evidence from these studies suggest that the effects of NO depend on the concentration and indicates that analysis of NOSs is necessary for defining the influence of $\mathrm{NO}$ on islet hormone release.
All three isoforms of nitric oxide synthase, nNOS, eNOS and iNOS, are expressed in the pancreas. Specific tissue and cellular localization of the NOS isoform determines its role in the regulation of pancreatic function [103]. nNOS is usually considered to be the major NOS isoform with multifunctional properties in pancreatic tissue. Besides ganglion cells and nerve fibers, nNOS is also expressed in pancreatic exocrine and islet cells. Furthermore, Lajoix et al. [73] found that nNOS and insulin were colocalized mainly in insulin secretory granules in $\beta$-cells. In addition, Rizzo and Piston [104] reported that the regulation of hexokinase IV localization and activity in $\beta$-cells is directly related to NO production and that the association of hexokinase IV with secretory granules occurs through its interaction with nNOS. These data suggest that the nNOS isoform is more conveniently situated to control insulin release than iNOS, which is localized in the cytoplasm [105]. We recently found that L-arginine treatment differentially affected nNOS immunopositivity in normal and diabetic pancreas, and thus probably insulin secretion [86]. In non-diabetic rats, faint nNOS immunopositivity was accompanied by a decrease in insulin plasma concentration, while in diabetic rats there was strong nNOS expression associated with restored insulin level in plasma and pancreatic tissue. These observations favor the assumption that $\mathrm{NO}$ acts as a positive modulator of insulin release and that nNOS mediates the effects of supplemented L-arginine in the diabetic pancreas.

The broad spectrum of beneficial effects due to Larginine in $\beta$-cells includes its action on intracellular protective mechanisms and energy state, both very important for $\beta$-cell structural and functional integrity 


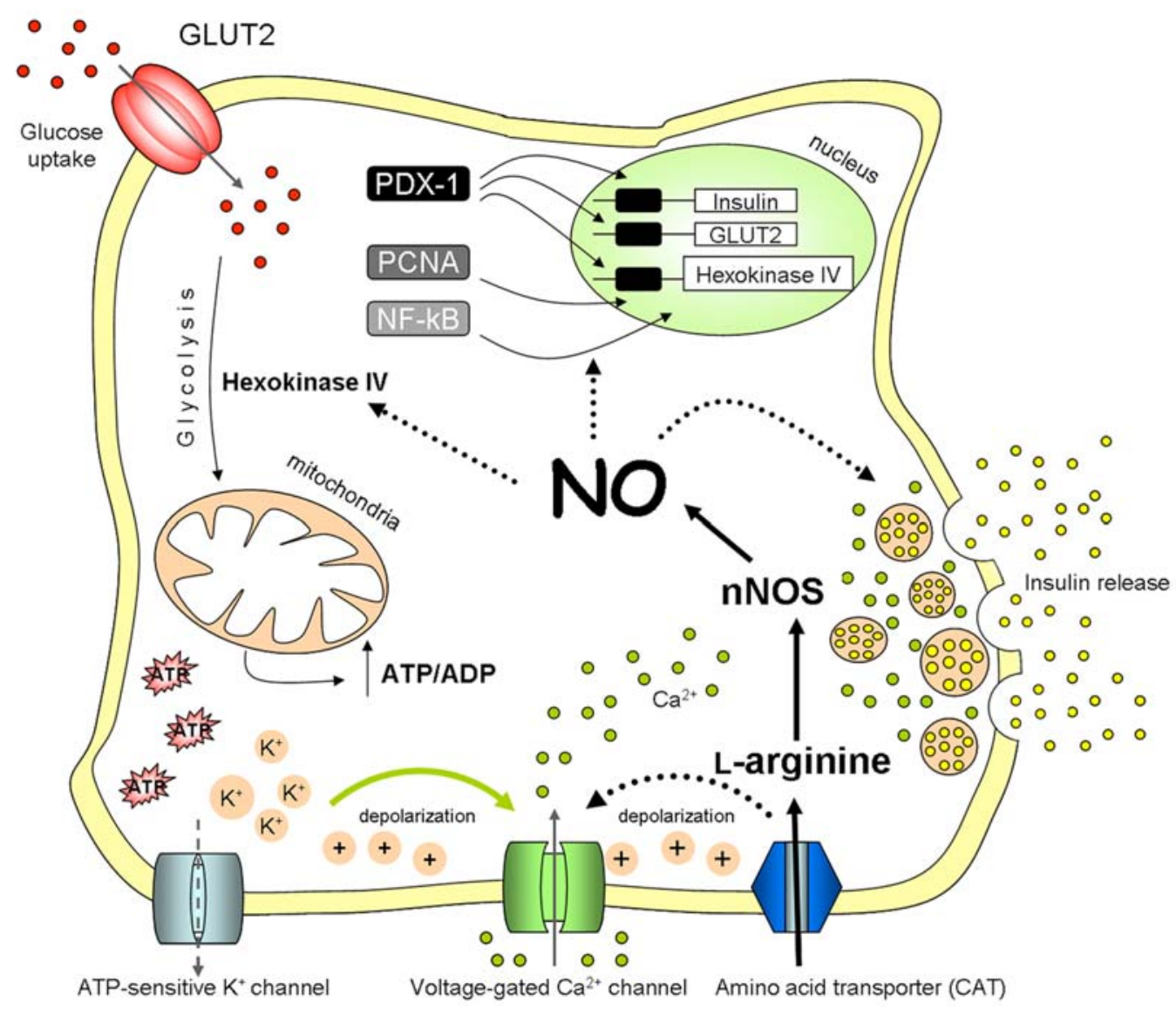

Figure 3: Scheme depicting possible mechanisms of action of L-arginine/NO in pancreatic $\beta$-cell. Entry of L-arginine into $\beta$-cell occurs via CAT. This leads to direct membrane depolarization, activation of voltage-gated $\mathrm{Ca}^{2+} \mathrm{channel}^{2} \mathrm{Ca}^{2+}$ influx, elevation of intracellular $\mathrm{Ca}^{2+}$ and discharge of insulin by exocytosis. Once inside the cells L-arginine can be metabolized by NOSs, of which nNOS plays important role acting on the multiple levels in $\beta$-cell. NO derived from nNOS, localized in secretory granules, interferes with insulin secretion coupling, through the regulation of hexokinase IV localization and activity as well as through the direct regulation of the process of exocytosis. Besides, nNOS/NO synthetic pathway increases cytoplasm-nuclear translocation of transcriptional factors important for $\beta$-cell function, proliferation and regeneration: i) PDX-1, the major regulator of the expression of insulin, GLUT2 and hexokinase IV; ii) PCNA and iii) NF-kB. Abbreviation: CAT, cationic transporters; NO, nitric oxide; nNOS, neuronal nitric oxide synthase; PDX-1, pancreatic duodenum homeobox-1; GLUT2, glucose transporter 2; PCNA, proliferating cell nuclear antigen; NF-kB, nuclear factor-kB.

$[86,106]$. Oral supplementation with L-arginine improves the glutathione-dependent part of antioxidative defense in the diabetic pancreas [86]. Krausse et al. [106] showed in vitro that increased provision of L-arginine to clonal $\beta$-cells resulted in enhanced synthesis of glutathione and antioxidative defense and a protective response against inflammatory challenge. Given that insulin-secreting cells have very low basal expression levels of antioxidant enzymes such as catalase and glutathione peroxidase [107, 108], the improvement in antioxidative defense by L-arginine could make these cells less prone to oxidative stress in the environment typical of type 1 and type 2 diabetes [109-112].

Direct evidence for the role of L-arginine in the regulation of $\beta$-cell energy metabolism has been provided recently by Krause et al. [106]. The authors reported that L-arginine increases glucose consumption and intermediary metabolism in $\beta$-cells. These results suggest that $L$-arginine could improve $\beta$-cell glucose responsiveness, one of the primary goals in the treatment of $\beta$-cells in diabetes [113].

Furthermore, the effects of L-arginine supplementation on insulin secretion in vivo may be more complex, related to its systemic actions not directly related to $\beta$-cells. This includes the effects on blood flow [114, 115], neurotransmission [116, 117] and exocrine secretion [118], all of which could affect insulin release itself.

\subsection{Insulin Resistance: Link with Obesity}

In addition to $\beta$-cell failure, type 2 diabetes is characterized by peripheral insulin resistance. In most 
cases, peripheral insulin resistance, defined as the attenuated response to insulin in fat tissue, liver and skeletal muscle, appears long before the development of hyperglycemia [82]. The etiology of insulin resistance is multifactorial including genetic and exogenous factors, first of all low physical activity and obesity. Obesity characterizes approximately $60-80 \%$ cases of diabetes type 2. It causes features of metabolic dysfunction in adipose tissue including reduced insulinstimulated glucose transport, reduced expression of glucose transporter 4 (GLUT4), altered expression of adipokines and adipocyte hypertrophy. Hypertrophy of adipose tissue develops when dietary intake of energy exceeds whole-body energy expenditure. In the case where the capacity of adipose tissue to store fatty acids is exhausted, the level of free fatty acids in blood increases and their mobilization and ectopic accumulation in skeletal muscle and liver occur. This triggers resistance to insulin in liver and skeletal muscle [119]. Resistance to the insulin-mediated suppression of hepatic gluconeogenesis and glycogenolysis increases glucose output from the liver, while in skeletal muscle insulin resistance leads to reduced glucose uptake. All these lead to hyperglycemia and further progression to type 2 diabetes. Therefore, type 2 diabetes is a particularly challenging clinical condition to treat because of the complex pathophysiological basis. The main research effort in the last few years in the prevention and treatment of diabetes type 2 has been to find ways to increase lipid metabolism in adipose tissue and regulate energy partitioning, i.e. treat obesity and/or to directly improve glucose uptake and metabolism.

\subsubsection{L-Arginine Reduces Obesity: Regulation of Fat Metabolism}

Positive effects of L-arginine on adipose tissue reduction have been documented in obese and nonobese rats and humans [120-124]. Fu et al. [120] showed that dietary L-arginine supplementation reduced body weight and epididymal and retroperitoneal fat weight in adult Zucker diabetic obese rats, a genetically obese model of diabetes type 2 . Similar changes were observed after supplementation of citrulline-rich watermelon to these animals [19] and after supplementation of L-arginine to diet-induced obese rats $[122,125]$. To date, only one clinical trial has confirmed the effect of L-arginine in reducing fat mass in obese diabetic subjects. Lucotti et al. [123] showed that L-arginine-induced a decrease in body weight was due to fat mass reduction when L-arginine was added to a hypocaloric diet and exercise in obese, insulin-resistant type 2 diabetic patients. In addition, a number of experimental and clinical studies have reported the beneficial effects of L-arginine on the serum lipid profile in diabetes including total cholesterol, low-density lipoproteins and triglyceride levels [125-127].

The outlined effects of L-arginine on fat mass are a result of its role in the regulation of adipocyte lipid metabolism. In vitro studies have revealed that arginine stimulates lipolysis in adipocytes and promotes the oxidation of long-chain fatty acids in insulin-sensitive tissues [121, 128, 129]. An in vivo study also showed that along with a reduction in fat mass, arginine induced an increase in the oxidation of octanoate in abdominal and epididymal adipose tissue in obese rats [120]. In contrast, L-arginine decreased the incorporation of palmitate and glucose into triglycerides in human adipocytes suggesting decreased lipogenesis $[122,129]$. The molecular mechanisms underlying such a metabolic shift in white fat cells from lipid storage toward lipid mobilization and fatty acid utilization after L-arginine dietary supplementation have been suggested. These include the regulation of gene expression and activity of the enzymes involved in lipid and glucose metabolism. Specifically, arginine supplementation down-regulates the expression of lipogenic genes, such as lipoprotein lipase (LPL), acetyl-CoA carboxylase (ACC) alpha, but up-regulates the expression of genes involved in lipolysis in porcine white adipose tissue, including hormone-sensitive lipase (HSL) [130]. Furthermore, L-arginine upregulates the expression of genes involved in fatty acid oxidation: nNOS, heme oxygenase- 3 and peroxisome proliferator-activated receptor- $\gamma$ coactivator $1 \alpha$ (PGC$1 \alpha)$, as has been shown in the adipose tissue of obese diabetic rats [120]. An increase in nNOS suggests that the effects of dietary L-arginine supplementation on lipid metabolism in white adipose tissue are mediated by NO. However, in vitro studies on the effect of NO donors on lipid metabolism in adipocytes produced controversial data, some of which confirmed the stimulatory effect, and some showed the opposite effect of NO on lipolysis. Such contradictory results could be due to differences in NO donors used and concentration of $\mathrm{NO}$, tissue origin, intracellular redox state etc. In vivo studies provided more consistent results demonstrating that the physiological level of NO, which is achived with L-arginine supplementation, increases lipolysis in rat adipose tissue [128].

In addition to the direct effect of L-arginine on white fat lipid metabolism, it can also regulate the level of the 
adipocyte-derived hormones, adipokines. With respect to the role that adipokines play in the central regulation of food intake and peripheral regulation of energy expenditure and insulin sensitivity, alterations in their synthesis and plasma levels contribute to diabetesassociated disturbances in whole-body energy homeostasis. It has been shown that increased plasma level of leptin, coupled with leptin resistance, is associated with fat accumulation [131]. Stingl et al. [132] found that L-arginine infusion transiently decreased the plasma level of leptin in insulin-deficient and hyperinsulinemic diabetic patients. A similar effect was observed after long-term dietary L-arginine supplementation in obese, insulin-resistant type 2 diabetic patients; L-arginine decreased leptin level and the leptin/adiponectin ratio [123]. Oral L-arginine supplementation can also induce a decrease in resistin expression in white adipose tissue, as we recently observed in L-arginine-treated animals (unpublished data). Such effect of L-arginine on the level of resistin could be beneficial in respect to pathology of type 2 diabetes, since the increase in resistin level positively correlate with increase in adiposity and decreased insulin sensitivity [133-135].

\subsubsection{Brown Adipose Tissue Stimulation: Strategy for Increasing Energy Expenditure in Diabetes}

Brown adipose tissue (BAT) is specialized for adaptive thermogenesis, the energy expenditure induced by cold exposure or diet. Fatty acid oxidation and heat production by BAT are due to intense metabolic activity because of the presence of a large number of mitochondria, and the expression of uncoupling protein 1 (UCP1), which uncouples ATP synthesis from the respiratory process to generate heat [136]. The main fuel, fatty acids, is provided both by BAT and white adipose tissue. Therefore, it is not surprising that in the last few years there has been particular interest in finding a way to stimulate BAT function or to induce the conversion from white to brown adipocytes as a strategy to control fat mass and obesity (conversion from energy storage to energy expenditure). This research is especially encouraging as the evidences for functional BAT in adult humans emerge [137, 138]. Furthermore, it has been shown that BAT activity is reduced in adult overweight or obese humans and is positively correlated with resting metabolic rate [139].

There is growing evidence to show that L-arginine has the potential to induce BAT function in physiological states and diabetes. Vasilijevic et al. [140] showed that L-arginine supplementation restored diabetes-induced disturbances in the molecular basis of thermogenesis (including UCP1 expression) in BAT of animals with type 1 diabetes. In addition, the stimulatory effects of L-arginine on BAT mass have been reported in diet-induced obese diabetic rats [141]. Our extensive research on BAT physiology has shown that the L-arginine/NO action on BAT involves structural, metabolic and molecular remodeling of this tissue, in terms of its functional activation. In that context, L-arginine supplementation to cold-acclimated rats induced BAT hyperplasia, proliferation and differentiation of brown adipocytes, increased tissue vascularization and innervation as well as mitochondriogenesis [142-145]. Such structural changes in BAT are accompanied by L-arginineinduced recruitment of the molecular program including key thermogenesis-related regulatory and effectors molecules: PGC-1 $\alpha$, peroxisome proliferator-activated receptor $\gamma$ (PPARY), vascular endothelial growth factor (VEGF), and UCP1 [146]. The effect of L-arginine on BAT functional activation involves improving the oxidative metabolism of this tissue through the regulation of key enzymes for glucose and fatty acid metabolism and energy state sensors (5'-AMPactivated protein kinase $\alpha$ - AMPKa and hypoxiainducible factor $1 \alpha-\mathrm{HIF}-1 \alpha$ ) [147].

\subsubsection{L-Arginine Improves Insulin Resistance: Regulation of Glucose Uptake and Metabolism}

The favorable effects of exogenous L-arginine in diabetes type 2 can also be attributed to its direct role in improving insulin sensitivity and glucose uptake and metabolism. It has been shown that dietary L-arginine supplementation ameliorates insulin sensitivity in an experimental model of diabetes as well as in diabetic patients [127, 148-150]. Data from the welL-know insulin sensitivity tests clearly show that L-arginine increases glucose uptake and metabolism in insulin sensitive tissues and suggest the involvement of the Larginine-NO producing pathway. The improvement in glucose metabolism by L-arginine could be a consequence of increased blood flow and tissue substrate supply due to NO-induced vasodilatation [128]. Vasodilatatory effects of NO could be mediated by NO itself or through its interference with the insulinsignaling pathway in the endothelium. Baron et al. [151, 152] showed that insulin-mediated vasodilatation is largely dependent on the action of insulin on NO release, whereas Petrie et al. [153] showed that endothelial NO synthesis and insulin sensitivity are positively correlated in healthy individuals. In type 2 
diabetic patients, L-arginine administration decreases vascular resistance and increases blood flow [149].

However, the increase in NO availability after Larginine supplementation could improve systemic insulin sensitivity independently of its vasodilatation effects. In support of this, insulin-sensitive tissues express NOS: skeletal muscles express all three isoforms while adipose tissue mainly expresses eNOS and iNOS [128, 154-156]. In addition, in vitro studies showed that NO per se affects glucose uptake: NO donors increase [157], while NOS inhibitors decrease glucose transport in isolated skeletal muscle [158].

The direct effect of NO on glucose uptake could be related to insulin signaling in skeletal muscle and adipose tissue. There is direct in vivo evidence that insulin stimulation of glucose uptake in skeletal muscle and adipose tissue is NO dependent. Roy et al. [159] showed that infusion of the NOS inhibitor, $N^{G}$ monomethyl-L-arginine (L-NMMA), in rats inhibited insulin-mediated glucose uptake in muscles and various adipose tissue depots, while Marliss et al. [160] reported that the increase in plasma level of this NOS inhibitor correlates with insulin resistance in obese and aging subjects.

Furthermore, it has been shown that NO stimulates glucose uptake in skeletal muscle and adipose tissue in an insulin-independent manner [149, 161, 162]. These effects of NO imply GLUT4 translocation independent of phosphorylation of the insulin receptor substrate and activation of phosphatidyl inositol 3 kinase. It has been shown that exercise-stimulated GLUT4 activation and glucose uptake is mediated by NO, and the existence of two different pools of GLUT4 transporter in skeletal muscles (exercise- and insulin- sensitive) has been demonstrated [163, 164]. McConell et al. [165] showed that L-arginine infusion increases glucose clearance during prolonged exercise independently of its effects on blood flow and insulin level. The potential of Larginine to increase glucose uptake independently of insulin could be of special importance in terms of its pharmacological potential in diabetes treatment.

In addition to increasing glucose uptake, NO can improve overall glucose metabolism acting on glucose oxidation in insulin-sensitive tissues. Sodium nitroprusside, a well-known NO donor, significantly increased lactate release and glucose oxidation in isolated skeletal muscle [166, 167], while L-NAME treatment of cold-acclimated animals decreased lactate dehydrogenase activity in skeletal muscle in vivo (unpublished data). Fu et al. [120] showed that dietary L-arginine supplementation enhanced glucose oxidation in the fat tissues of obese rats. It seems likely that L-arginine is also able to enhance glucose metabolism in the liver. Supplementation with dietary coconut kernel protein, which is rich in L-arginine, resulted in reversal of diabetes-induced decreased activities of hexokinase and pyruvate kinase in the liver of diabetic rats [168]. In addition, L-arginine increased glucokinase activity in cultured rat hepatocytes [169].

\section{CENTRAL MEDIATOR OF THE METABOLIC EFFECTS OF L-ARGININE IN DIABETES - AMPKa}

AMPKa is recognized as an important sensor of cellular energy status and as an effector in maintaining energy balance at the whole body level. It is activated by an increase in the AMP/ATP ratio, and acts by switching on ATP-producing pathways and switching off ATP-consuming pathways [170]. Thus, it plays an important role in regulation of the metabolism of energy substrates, glucose and fatty acids, in many tissues. In skeletal muscle, AMPKa increases glucose oxidation and glucose uptake, by increasing the expression and translocation of GLUT4 [171-175]. AMPKa signaling is also crucial in the regulation of fatty acid oxidation in liver and skeletal muscle $[171,176]$. Acting through the inhibition of ACC, AMPKa favors fatty acids oxidation and suppresses their synthesis. In addition it has been shown that activation of AMPKa signaling inhibits gluconeogenesis in the liver [177].

The regulatory role of AMPKa on lipid and glucose metabolic pathways, along with previously discussed metabolic problems in diabetes, suggests that AMPKa could be a promising pharmaceutical target in the treatment of diabetes and associated metabolic disturbances. The anti-hyperglycemic drug, metformin, which is already incorporated in the therapy of diabetes type 2, activates AMPKa both in intact cells and in vivo [178]. Furthermore, it has been shown that activation of AMPKa by this anti-diabetic agent is mediated by NO, specifically with peroxynitrite (ONOO') [179]. However, the hypoglycemic effect of metformin is mainly due to its inhibitory effect on glucose synthesis in the liver, as the concentration of the drug in the peripheral circulation (as opposed to the portal vein, which supplies the liver direct from the gut) may not be sufficiently high to yield significant AMPKa activation in other tissues, including skeletal muscle and adipose tissue. In contrast, it has been shown that oral supplementation of L-arginine induces the expression and/or activation of AMPKa in adipose tissue [120], 
skeletal muscle [175, 180] and liver [181]. Thus, Larginine may have an advantage over metformin in the regulation of whole-body energy metabolism. It seems that AMPKa may be a unique mediator in the beneficial effects of dietary L-arginine supplementation in obesity and insulin resistance in diabetes type 2 . This hypothesis is supported by the data reported by $\mathrm{Fu}$ et al. [120], which showed that along with decreased fat mass in diabetic obese rats, dietary L-arginine supplementation also increased gene expression of AMPKa in these tissues. In addition, Linden et al. [179] reported recently that the stimulatory effect of Larginine on glucose clearance rate included activation of AMPKa signaling in skeletal muscle.

Furthermore, the positive effect of L-arginine on $\beta$ cell dysfunction may be mediated by AMPKa. Krause et al. [106] showed that L-arginine induces activation of AMPK $\alpha$ in clonal $\beta$-cells and mouse islets. The role of AMPK $\alpha$ in $\beta$-cell stimulus-secretion coupling is unclear [182], but as AMPK $\alpha$ triggers energy-producing pathways, its activation could positively interfere with insulin secretion. It has also been suggested that activation of AMPK $\alpha$ may contribute to $\beta$-cell functional integrity [183] and consequently serve to counter $\beta$-cell glucolipotoxicity.

\section{SUMMARY AND PERSPECTIVES}

The understanding that diabetes is a chronic multifactorial disease, which is poorly treated with the available therapeutic approaches, has stimulated a renewed interest in the development of novel safe and effective therapies for this disease. Dietary components represent an attractive source of potential therapeutics for diabetes due to their wide availability, natural metabolism and low cost. This paper aimed to review the already known facts on L-arginine supplementation as a potentially useful nutritional strategy for the prevention and management of diabetes, and to emphasize and open new issues for examination in coming years.

The discovery that oral supplementation of Larginine has an amazing capacity to increase the $\beta$-cell population in diabetes is highly important as the main effort in regenerative medicine is to stimulate $\beta$-cell regeneration in vivo. As the L-arginine/NO pathway positively interferes with insulin synthesis and secretion

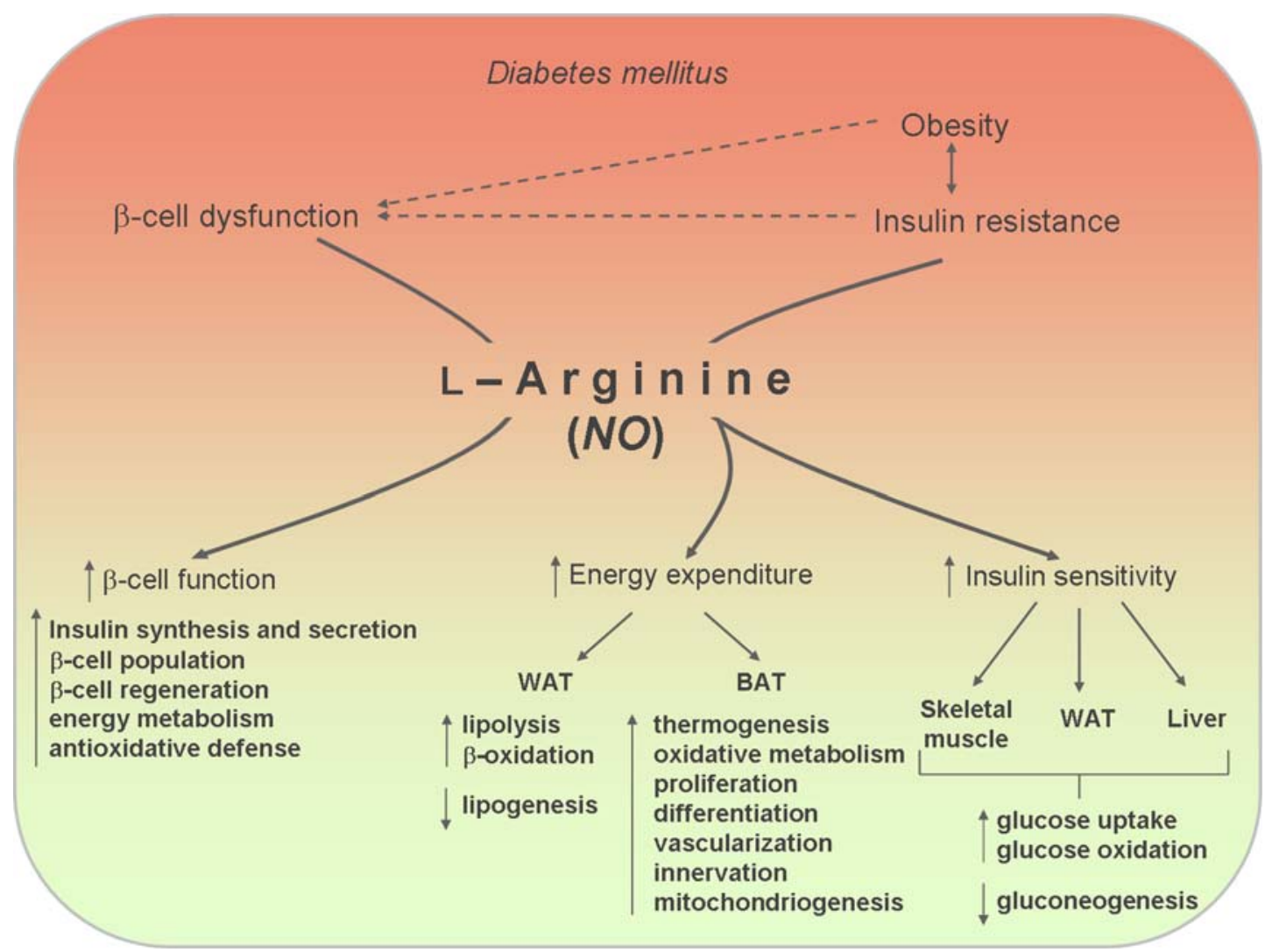

Figure 4: Overview of multiple beneficial effects of L-arginine/NO pathway in diabetes; regulation of $\beta$-cell function, energy expenditure and insulin sensitivity. Cellular processes and metabolic pathways that are targets of $L$-arginine action are represented. The symbol " $\uparrow$ " denotes up-regulatory, while the symbol " $\downarrow$ " indicates down-regulatory effects of L-arginine. Abbreviation: WAT, white adipose tissue; BAT, brown adipose tissue. 
pathways in $\beta$-cells, this amino acid may be used, along with insulin therapy, to normalize insulin levels in diabetes.

The vast majority of the anti-diabetic actions of Larginine originate from its role in the regulation of the metabolism of the key energy substrates: lipid and glucose. Due to the effects of L-arginine in improving lipid and glucose metabolism as well as glucose uptake, this amino acid may be important in the control of the complex pathophysiological basis of type 2 diabetes, including obesity and insulin resistance. These multilevel actions may provide L-arginine with an advantage over the existing anti-diabetic drugs (metformin) and suggest that L-arginine could be an excellent nutritional support to increase energy expenditure (exercise) or reduce energy intake (diet) in the treatment of diabetes type 2 and associated pathology (Figure 4).

In addition, it is hoped that the presented data on the effects of L-arginine in diabetes will stimulate and provide a good basis for further research into the antidiabetic potential of L-arginine-rich food. With respect to dietary intake, several issues require to be fully elucidated including L-arginine absorption, its tissue distribution and bioavailability, and tissue-specific metabolic pathways. Also, the physiological consequences of oral L-arginine supplementation in diabetes should be reconsidered in light of growing knowledge on the complex signaling pathways and molecular targets of its metabolic products, particularly NO. Some aspects of L-arginine action in diabetes are only experimentally proved, therefore clinical studies are needed to support our expectations regarding this nutritionally important amino acid in diabetes prevention and treatment.

\section{ACKNOWLEDGEMENTS}

This work was supported by the Ministry of Education, Science and Technological development of the Republic of Serbia, Grants No 173054 and 173055.

\section{REFERENCES}

[1] Schulze E, Steiger E. Uber das. Arginin. Z Physiol Chem 1886; 11: 43-65.

[2] Palmer RM, Rees DD, Ashton DS, Moncada S. L-arginine is the physiological precursor for the formation of nitric oxide in endothelium-dependent relaxation. Biochem Biophys Res Commun 1988; 153: 1251-6. http://dx.doi.org/10.1016/S0006-291X(88)81362-7

[3] Ignarro LJ, Buga GM, Wood KS, Byrns RE, Chaudhuri G. Endothelium-derived relaxing factor produced and released from artery and vein is nitric oxide. Proc Natl Acad Sci U S A 1987 84: 9265-9.

http://dx.doi.org/10.1073/pnas.84.24.9265

[4] Palmer RM, Ferrige AG, Moncada S. Nitric oxide release accounts for the biological activity of endothelium-derived relaxing factor. Nature 1987; 327: 524-6. http://dx.doi.org/10.1038/327524a0

[5] Wu G, Morris SM Jr. Arginine metabolism: nitric oxide and beyond. Biochem J 1998; 336: 1-17.

[6] Dhanakoti SN, Brosnan JT, Brosnan ME, Herzberg GR. Net renal arginine flux in rats is not affected by dietary arginine or dietary protein intake. J Nutr 1992; 122: 1127-34.

[7] Castillo L, Chapman TE, Sanchez M, et al. Plasma arginine and citrulline kinetics in adults given adequate and argininefree diets. Proc Natl Acad Sci U S A 1993; 90: 7749-53. http://dx.doi.org/10.1073/pnas.90.16.7749

[8] Castillo L, Ajami A, Branch S, et al. Plasma arginine kinetics in adult man: response to an arginine-free diet. Metabolism 1994: 43: 114-22. http://dx.doi.org/10.1016/0026-0495(94)90166-X

[9] Barbul A. Arginine: biochemistry, physiology, and therapeutic implications. JPEN J Parenter Enteral Nutr 1986; 10: 227-38. http://dx.doi.org/10.1177/0148607186010002227

[10] Flynn NE, Meininger CJ, Haynes TE, Wu G. The metabolic basis of arginine nutrition and pharmacotherapy. Biomed Pharmacother 2002; 56: 427-38. http://dx.doi.org/10.1016/S0753-3322(02)00273-1

[11] Palm F, Friederich M, Carlsson PO, Hansell P, Teerlink T, Liss $P$. Reduced nitric oxide in diabetic kidneys due to increased hepatic arginine metabolism: implications for renomedullary oxygen availability. Am J Physiol Renal Physiol 2008; 294: 30-7.

http://dx.doi.org/10.1152/ajprenal.00166.2007

[12] Pieper GM, Dondlinger LA. Plasma and vascular tissue arginine are decreased in diabetes: acute arginine supplementation restores endothelium-dependent relaxation by augmenting cGMP production. J Pharmacol Exp Ther 1997; 283: 684-91.

[13] Taboada MC, Rodriguez B, Millán R, Míguez I. Role of dietary l-arginine supplementation on serum parameters and intestinal enzyme activities in rats fed an excess-fat diet. Biomed Pharmacother 2006; 60: 10-3. http://dx.doi.org/10.1016/j.biopha.2005.07.014

[14] Witte MB, Thornton FJ, Tantry U, Barbul A. L-Arginine supplementation enhances diabetic wound healing: involvement of the nitric oxide synthase and arginase pathways. Metabolism 2002; 51: 1269-73. http://dx.doi.org/10.1053/meta.2002.35185

[15] Bode-Böger SM, Böger $\mathrm{RH}$, Creutzig $\mathrm{A}$, et al. L-arginine infusion decreases peripheral arterial resistance and inhibits platelet aggregation in healthy subjects. Clin Sci (Lond) 1994; 87: 303-10.

[16] Phivthong-ngam L, Bode-Böger SM, Böger RH, et al. Dietary L-arginine normalizes endothelin-induced vascular contractions in cholesterol-fed rabbits. J Cardiovasc Pharmacol 1998; 32: 300-7. http://dx.doi.org/10.1097/00005344-199808000-00019

Böger RH, Ron ES. L-Arginine improves vascular function by overcoming deleterious effects of ADMA, a novel cardiovascular risk factor. Altern Med Rev 2005; 10: 14-23.

[18] Silk DB, Grimble GK, Rees RG. Protein digestion and amino acid and peptide absorption. Proc Nutr Soc 1985; 44: 63-72. http://dx.doi.org/10.1079/PNS19850011

[19] Wu G, Collins JK, Perkins-Veazie $P$, et al. Dietary supplementation with watermelon pomace juice enhances arginine availability and ameliorates the metabolic syndrome in Zucker diabetic fatty rats. J Nutr 2007; 137: 2680-5. 
[20] Hou ZP, Yin YL, Huang RL, et al. Rice protein concentrate partially replaces dried whey in the diet for early-weaned piglets and improves their growth performance. J Sci Food Agric 2008; 88: 1187-1193.

http://dx.doi.org/10.1002/jsfa.3196

[21] King DE, Mainous AG, Geesey ME. Variation in L-arginine intake follow demographics and lifestyle factors that may impact cardiovascular disease risk. Nutr Res 2008; 28: 21-4. http://dx.doi.org/10.1016/j.nutres.2007.11.003

[22] Böger $\mathrm{RH}$. The pharmacodynamics of L-arginine. J Nutr 2007; 137: 1650-5.

[23] Windmueller HG, Spaeth AE. Metabolism of absorbed aspartate, asparagine, and arginine by rat small intestine in vivo. Arch Biochem Biophys 1976; 175: 670-6. http://dx.doi.org/10.1016/0003-9861(76)90558-0

[24] Castillo L, Chapman TE, Yu YM, Ajami A, Burke JF, Young VR. Dietary arginine uptake by the splanchnic region in adult humans. Am J Physiol 1993; 265: 532-9.

[25] Kirk SJ, Hurson M, Regan MC, Holt DR, Wasserkrug HL, Barbul A. Arginine stimulates wound healing and immune function in elderly human beings. Surgery 1993; 114: 155-60.

[26] Brittenden J, Heys SD, Ross J, Park KG, Eremin O. Natural cytotoxicity in breast cancer patients receiving neoadjuvant chemotherapy: effects of L-arginine supplementation. Eur $\mathrm{J}$ Surg Oncol 1994; 20: 467-72.

[27] Helmbrecht GD, Farhat MY, Lochbaum L, et al. L-arginine reverses the adverse pregnancy changes induced by nitric oxide synthase inhibition in the rat. Am J Obstet Gynecol 1996; 175: 800-5. http://dx.doi.org/10.1016/S0002-9378(96)80002-0

[28] Bortolotti M, Brunelli F, Sarti P, Miglioli M. Clinical and manometric effects of $\mathrm{L}$-arginine in patients with chest pain and oesophageal motor disorders. Ital J Gastroenterol Hepatol 1997; 29: 320-4.

[29] Facchinetti F, Longo M, Piccinini F, Neri I, Volpe A. Larginine infusion reduces blood pressure in preeclamptic women through nitric oxide release. J Soc Gynecol Investig 1999; 6: 202-7.

http://dx.doi.org/10.1016/S1071-5576(99)00017-9

[30] Walker HA, McGing E, Fisher I, et al. Endotheliumdependent vasodilation is independent of the plasma Larginine/ADMA ratio in men with stable angina: lack of effect of oral L-arginine on endothelial function, oxidative stress and exercise performance. J Am Coll Cardiol 2001; 38: 499505.

http://dx.doi.org/10.1016/S0735-1097(01)01380-8

[31] Tangphao O, Chalon S, Coulston AM, et al. L-arginine and nitric oxide-related compounds in plasma: comparison of normal and arginine-free diets in a 24-h crossover study. Vasc Med 1999; 4: 27-32.

[32] Evans RW, Fernstrom JD, Thompson J, Morris SM Jr, Kuller $\mathrm{LH}$. Biochemical responses of healthy subjects during dietary supplementation with L-arginine. J Nutr Biochem 2004; 15: 534-9.

http://dx.doi.org/10.1016/j.jnutbio.2004.03.005

[33] Luiking YC, Weusten BL, Portincasa P, Van Der Meer R, Smout AJ, Akkermans LM. Effects of long-term oral Larginine on esophageal motility and gallbladder dynamics in healthy humans. Am J Physiol 1998; 274: 984-91.

[34] Grimble GK. Adverse gastrointestinal effects of arginine and related amino acids. J Nutr 2007; 137: 1693-1701.

[35] Park KGM. The Sir David Cuthbertson Medal Lecture 1992. The immunological and metabolic effects of L-arginine in human cancer. Proc Nutr Soc 1993; 52: 387-401. http://dx.doi.org/10.1079/PNS19930080

[36] Tomé LA, Yu L, de Castro I, Campos SB, Seguro AC. Beneficial and harmful effects of $L$-arginine on renal ischaemia. Nephrol Dial Transplant 1999; 14: 1139-45. http://dx.doi.org/10.1093/ndt/14.5.1139
[37] AHFS Drug Information. Bethesda, MD: American Society of Hospital Pharmacists. 2000: 2306-7.

[38] Cauwels A, Janssen B, Buys E, Sips P, Brouckaert P. Anaphylactic shock depends on PI3K and eNOS-derived NO. $\mathrm{J}$ Clin Invest 2006; 116: 2244-51. http://dx.doi.org/10.1172/JCl25426

[39] Amir S, English AM. An inhibitor of nitric oxide production, NG-nitro-L-arginine-methyl ester, improves survival in anaphylactic shock. Eur J Pharmacol 1991; 203: 125-7. http://dx.doi.org/10.1016/0014-2999(91)90800-6

[40] Takano H, Liu W, Zhao Z, et al. N(G)-Nitro-L-arginine methyl ester, but not methylene blue, attenuates anaphylactic hypotension in anesthetized mice. J Pharmacol Sci 2007; 104: 212-7. http://dx.doi.org/10.1254/jphs.FP0070169

[41] Schulman SP, Becker L C, Kass DA, et al. L-arginine therapy in myo-cardial infarction. The Vascular Interaction with Age in Myocardial Infarction (VINTAGE MI) randomized clinical trial. JAMA 2006; 295: 58-64.

http://dx.doi.org/10.1001/jama.295.1.58

[42] Takano H, Lim HB, Miyabara Y, Ichinose T, Yoshikawa T, Sagai M. Oral administration of $\mathrm{L}$-arginine potentiates allergen-induced airway inflammation and expression of interleukin-5 in mice. J Pharmacol Exp Ther 1998; 286: 76771.

[43] Chambers DC, Ayres JG. Effect of nebulised L- and Darginine on exhaled nitric oxide in steroid naive asthma. Thorax 2001; 56: 602-6. http://dx.doi.org/10.1136/thorax.56.8.602

[44] Tankersley RW. Amino acid requirements of herpes simplex virus in human cells. J Bacteriol 1964; 87: 609-13

[45] Yeatman TJ, Risley GL, Brunson ME. Depletion of dietary arginine inhibits growth of metastatic tumor. Arch Surg 1991; 126: $1376-82$.

http://dx.doi.org/10.1001/archsurg.1991.01410350066010

[46] Grossie VB. Citrulline and arginine increase the growth of the ward colon tumor in parenterally fed rats. Nutr Cancer 1996; 26: 91-7. http://dx.doi.org/10.1080/01635589609514466

[47] Appleton J. Arginine: Clinical potential of a semi-essential amino. Altern Med Rev 2002; 7: 512-22.

[48] Eeagle H. Amino acid metabolism in mammalian cell cultures. Science 1959; 130: 432-7. http://dx.doi.org/10.1126/science.130.3373.432

[49] Jackson MJ, Beaudet AL, O'Brien WE. Mammalian urea cycle enzymes. Annu Rev Genet 1986; 20: 431-64. http://dx.doi.org/10.1146/annurev.ge.20.120186.002243

[50] Morris Sm Jr. Arginine synthesis, metabolism and transport: Regulators of nitric oxide synthesis. In: Laskin JD, Laskin DL, editors. Cellular and Molecular Biology of Nitric oxide. New York: Marcel Dekker, Inc.; 1999 p. 57-85.

[51] Featherston WR, Rogers QR, Freedland RA. Relative importance of kidney and liver in synthesis of arginine by the rat. Am J Physiol 1973; 224: 127-9.

[52] Ryall J, Nguyen M, Bendayan M, Shore GC. Expression of nuclear genes encoding the urea cycle enzymes, carbamoylphosphate synthetase I and ornithine carbamoyl transferase, in rat liver and intestinal mucosa. Eur J Biochem 1985; 152: 287-92.

http://dx.doi.org/10.1111/j.1432-1033.1985.tb09196.x

[53] Levillain O, Hus-Citharel A, Morel F, Bankir L. Localization of arginine synthesis along rat nephron. Am J Physiol 1990; 259: 916-23.

[54] Blachier F, M'Rabet-Touil H, Posho L, Darcy-Vrillon B, Duée $\mathrm{PH}$. Intestinal arginine metabolism during development. Evidence for de novo synthesis of L-arginine in newborn pig enterocytes. Eur J Biochem 1993; 216: 109-17. http://dx.doi.org/10.1111/j.1432-1033.1993.tb18122.x 
[55] Wu G, Knabe DA, Yan W, Flynn NE. Glutamine and glucose metabolism in enterocytes of the neonatal pig. Am J Physiol 1995; 268: 334-42.

[56] Herzfeld A, Raper SM. Enzymes of ornithine metabolism in adult and developing rat intestine. Biochim Biophys Acta 1976; 428: 600-10. http://dx.doi.org/10.1016/0304-4165(76)90188-4

[57] Hurwitz R, Kretchmer N. Development of argininesynthesizing enzymes in mouse intestine. Am J Physiol. 1986; 251: 103-10.

[58] Yu YM, Burke JF, Tompkins RG, Martin R, Young VR. Quantitative aspects of interorgan relationships among arginine and citrulline metabolism. Am J Physiol 1996; 271: 1098-109.

[59] Morris SM Jr. Regulation of enzymes of urea and arginine synthesis. Annu Rev Nutr 1992; 12: 81-101. http://dx.doi.org/10.1146/annurev.nu.12.070192.000501

[60] Wu G, Bazer FW, Davis TA, et al. Arginine metabolism and nutrition in growth, health and disease. Amino Acids 2009; 37: $153-68$

http://dx.doi.org/10.1007/s00726-008-0210-y

[61] Jenkinson CP, Grody WW, Cederbaum SD. Comparative properties of arginases. Comp Biochem Physiol B Biochem Mol Biol 1996; 114: 107-32. http://dx.doi.org/10.1016/0305-0491(95)02138-8

[62] Malaisse WJ, Blachier F, Mourtada A, et al. Stimulussecretion coupling of arginine-induced insulin release. Metabolism of L-arginine and L-ornithine in pancreatic islets. Biochim Biophys Acta 1989; 1013: 133-43. http://dx.doi.org/10.1016/0167-4889(89)90041-4

[63] Gotoh T, Sonoki T, Nagasaki A, Terada K, Takiguchi M, Mori M. Molecular cloning of cDNA for nonhepatic mitochondrial arginase (arginase II) and comparison of its induction with nitric oxide synthase in a murine macrophage-like cell line. FEBS Lett 1996; 395: 119-22. http://dx.doi.org/10.1016/0014-5793(96)01015-0

[64] Vockley JG, Jenkinson CP, Shukla H, Kern RM, Grody WW, Cederbaum SD. Cloning and characterization of the human type II arginase gene. Genomics 1996; 38: 118-23. http://dx.doi.org/10.1006/geno.1996.0606

[65] Pegg AE, Wechter R, Pakala R, Bergeron RJ. Effect of N1,N12-bis(ethyl)spermine and related compounds on growth and polyamine acetylation, content, and excretion in human colon tumor cells. J Biol Chem 1989; 264: 11744-9.

[66] Sjöholm A. Role of polyamines in the regulation of proliferation and hormone production by insulin-secreting cells. Am J Physiol 1993; 264: 501-18.

[67] Ackermann JM, Pegg AE, McCloskey DE. Drugs affecting the cell cycle via actions on the polyamine metabolic pathway. Prog Cell Cycle Res 2003; 5: 461-8.

[68] Stone JR, Marletta MA. Spectral and kinetic studies on the activation of soluble guanylate cyclase by nitric oxide. Biochemistry 1996; 35: 1093-9. http://dx.doi.org/10.1021/bi9519718

[69] Moncada S, Palmer RM, Higgs EA. Nitric oxide: physiology, pathophysiology, and pharmacology. Pharmacol Rev 1991; 43: 109-42.

[70] Alderton WK, Cooper CE, Knowles RG. Nitric oxide synthases: structure, function and inhibition. Biochem $\mathrm{J}$ 2001; 357: 593-615. http://dx.doi.org/10.1042/0264-6021:3570593

[71] Stuehr DJ. Structure-function aspects in the nitric oxide synthases. Annu Rev Pharmacol Toxicol 1997; 37: 339-59. http://dx.doi.org/10.1146/annurev.pharmtox.37.1.339

[72] Govers R, Oess S. To NO or not to NO: 'where?' is the question. Histol Histopathol 2004; 19: 585-605.
[73] Lajoix $A D$, Reggio $H$, Chardès $T$, et al. A neuronal isoform of nitric oxide synthase expressed in pancreatic beta-cells controls insulin secretion. Diabetes 2001; 50: 1311-23. http://dx.doi.org/10.2337/diabetes.50.6.1311

[74] Böger RH, Bode-Böger SM. The clinical pharmacology of Larginine. Annu Rev Pharmacol Toxicol 2001; 41: 79-99. http://dx.doi.org/10.1146/annurev.pharmtox.41.1.79

[75] Tsikas D, Böger RH, Sandmann J, Bode-Böger SM, Frölich JC. Endogenous nitric oxide synthase inhibitors are responsible for the L-arginine paradox. FEBS Lett 2000; 478: 1-3. http://dx.doi.org/10.1016/S0014-5793(00)01686-0

[76] Förstermann U, Closs El, Pollock JS, et al. Nitric oxide synthase isozymes. Characterization, purification, molecular cloning, and functions. Hypertension 1994; 23: 1121-31. http://dx.doi.org/10.1161/01.HYP.23.6.1121

[77] Böger RH. Asymmetric dimethylarginine, an endogenous inhibitor of nitric oxide synthase, explains the "L-arginine paradox" and acts as a novel cardiovascular risk factor. $J$ Nutr 2004; 134: 2842-7.

[78] Joshi MS, Ferguson TB Jr, Johnson FK, Johnson RA, Parthasarathy S, Lancaster JR Jr. Receptor-mediated activation of nitric oxide synthesis by arginine in endothelial cells. Proc Natl Acad Sci U S A 2007; 104: 9982-7. http://dx.doi.org/10.1073/pnas.0506824104

[79] García-Cardeña G, Fan R, Stern DF, Liu J, Sessa WC Endothelial nitric oxide synthase is regulated by tyrosine phosphorylation and interacts with caveolin-1. J Biol Chem 1996; 271: 27237-40. http://dx.doi.org/10.1074/jbc.271.44.27237

[80] García-Cardeña G, Martasek P, Masters BS, et al. Dissecting the interaction between nitric oxide synthase (NOS) and caveolin. Functional significance of the NOS caveolin binding domain in vivo. J Biol Chem 1997; 272: 25437-40. http://dx.doi.org/10.1074/jbc.272.41.25437

[81] Atkinson MA, Bluestone JA, Eisenbarth GS, et al. How does type 1 diabetes develop?: the notion of homicide or $\beta$-cell suicide revisited. Diabetes 2011; 60: 1370-9.

http://dx.doi.org/10.2337/db10-1797

[82] Saltier AR, Kahn CR. Insulin signaling and the regulation of glucose and lipid metabolism. Nature 2001; 414: 799-806. http://dx.doi.org/10.1038/414799a

[83] Halban PA, German MS, Kahn SE, Weir GC. Current status of islet cell replacement and regeneration therapy. J Clin Endocrinol Metab 2010; 95: 1034-43. http://dx.doi.org/10.1210/jc.2009-1819

[84] Swenne I. Effects of aging on the regenerative capacity of the pancreatic B-cell of the rat. Diabetes 1983; 32: 14-9. http://dx.doi.org/10.2337/diabetes.32.1.14

[85] Bouwens L, Klöppel G. Islet cell neogenesis in the pancreas. Virchows Arch 1996; 427: 553-60. http://dx.doi.org/10.1007/BF00202885

[86] Vasilijević A, Buzadžić B, Korać A, Petrović V, Janković A Korać B. Beneficial effects of L-arginine nitric oxideproducing pathway in rats treated with alloxan. J Physiol 2007; 584: 921-33.

\section{http://dx.doi.org/10.1113/jphysiol.2007.140277}

[87] McKinnon CM, Docherty K. Pancreatic duodenal homeobox1 , PDX-1, a major regulator of beta cell identity and function. Diabetologia 2001; 44: 1203-14. http://dx.doi.org/10.1007/s001250100628

[88] Gagliardino JJ, Del Zotto H, Massa L, Flores LE, Borelli MI. Pancreatic duodenal homeobox-1 and islet neogenesisassociated protein: a possible combined marker of activateable pancreatic cell precursors. J Endocrinol 2003; 177: 249-59. http://dx.doi.org/10.1677/joe.0.1770249

[89] De Haro-Hernández R, Cabrera-Muñoz L, Méndez JD. Regeneration of beta-cells and neogenesis from small ducts 
or acinar cells promote recovery of endocrine pancreatic function in alloxan-treated rats. Arch Med Res 2004; 35: 11420.

http://dx.doi.org/10.1016/..arcmed.2003.10.001

[90] Lardon J, Huyens N, Rooman I, Bouwens L. Exocrine cell transdifferentiation in dexamethasone-treated rat pancreas. Virchows Arch 2004; 444: 61-5. http://dx.doi.org/10.1007/s00428-003-0930-z

[91] Okamoto H, Akiyama $\mathrm{T}$, Nata $\mathrm{K}$, et al. Reg (Regenerating gene) expression by PARP and NF-kB. Med Sci Monit 2003; 9: 50-60.

[92] Kaneto $\mathrm{H}$, Nakatani $\mathrm{Y}$, Kawamori D, et al. Role of oxidative stress, endoplasmic reticulum stress, and c-Jun $\mathrm{N}$-terminal kinase in pancreatic beta-cell dysfunction and insulin resistance. Int J Biochem Cell Biol 2005; 37: 1595-608. http://dx.doi.org/10.1016/j.biocel.2005.04.003

[93] Salil G, Nevin KG, Rajamohan T. Arginine-rich coconut kernel diet influences nitric oxide synthase activity in alloxan diabetic rats. J Sci Food Agric 2012; 92: 1903-8. http://dx.doi.org/10.1002/jsfa.5558

[94] Méndez JD, Arreola MA. Effect of L-arginine on pancreatic arginase activity and polyamines in alloxan treated rats. Biochem Int 1992; 28: 569-75.

[95] Méndez JD, De Haro Hernández R. L-arginine and polyamine administration protect $\beta$-cells against alloxan diabetogenic effect in Sprague-Dawley rats. Biomed Pharmacother 2005; 59: 283-9. http://dx.doi.org/10.1016/i.biopha.2005.05.006

[96] Adeghate E, Ponery AS, El-Sharkawy T, Parvez H. Larginine stimulates insulin secretion from the pancreas of normal and diabetic rats. Amino Acids 2001; 21: 205-9. http://dx.doi.org/10.1007/s007260170028

[97] Ishii M, Shimizu S, Watabe T, Kiuchi Y. Insulin Secretion in Response to L-Arginine under Decreasing Tetrahydrobiopterin Content. Pteridines 2008; 19: 93-100.

[98] Blachier F, Mourtada A, Sener A, Malaisse WJ. Stimulussecretion coupling of arginine-induced insulin release. Uptake of metabolized and nonmetabolized cationic amino acids by pancreatic islets. Endocrinology 1989; 124: 134-41. http://dx.doi.org/10.1210/endo-124-1-134

[99] Newsholme P, Brennan L, Rubi B, Maechler P. New insights into amino acid metabolism, beta-cell function and diabetes. Clin Sci (Lond) 2005; 108: 185-94 http://dx.doi.org/10.1042/CS20040290

[100] Jimenez-Feltstrom J, Lundquist I, Obermuller S, Salehi A. Insulin feedback actions: complex effects involving isoforms of islet nitric oxide synthase. Regul Pept 2004; 122: 109-18. http://dx.doi.org/10.1016/j.regpep.2004.06.004

[101] Laychock SG, Modica ME, Cavanaugh CT. L-arginine stimulates cyclic guanosine $3^{\prime}, 5^{\prime}$-monophosphate formation in rat islets of Langerhans and RINm5F insulinoma cells: evidence for L-arginine:nitric oxide synthase. Endocrinology 1991; 129: 3043-52.

http://dx.doi.org/10.1210/endo-129-6-3043

[102] Panagiotidis G, Akesson B, Rydell EL, Lundquist I. Influence of nitric oxide synthase inhibition, nitric oxide and hydroperoxide on insulin release induced by various secretagogues. Br J Pharmacol 1995; 114: 289-96. http://dx.doi.org/10.1111/j.1476-5381.1995.tb13225.x

[103] Henningsson R, Alm P, Lindström E, Lundquist I. Chronic blockade of NO synthase paradoxically increases islet NO production and modulates islet hormone release. Am J Physiol Endocrinol Metab 2000; 279: 95-107.

[104] Rizzo MA, Piston DW. Regulation of beta cell glucokinase by S-nitrosylation and association with nitric oxide synthase. $\mathrm{J}$ Cell Biol 2003; 161: 243-8. http://dx.doi.org/10.1083/jcb.200301063

[105] Knowles RG, Moncada S. Nitric oxide synthases in mammals. Biochem J 1994; 298: 249-58.
[106] Krause MS, McClenaghan NH, Flatt PR, de Bittencourt PI, Murphy $C$, Newsholme P. L-arginine is essential for pancreatic $\beta$-cell functional integrity, metabolism and defense from inflammatory challenge. J Endocrinol 2011; 211: 87-97. http://dx.doi.org/10.1530/JOE-11-0236

[107] Lenzen S, Drinkgern J, Tiedge M. Low antioxidant enzyme gene expression in pancreatic islets compared with various other mouse tissues. Free Radic Biol Med 1996; 20: 463-6. http://dx.doi.org/10.1016/0891-5849(96)02051-5

[108] Tiedge M, Lortz S, Drinkgern J, Lenzen S. Relation between antioxidant enzyme gene expression and antioxidative defense status of insulin-producing cells. Diabetes 1997; 46: 1733-42.

http://dx.doi.org/10.2337/diabetes.46.11.1733

[109] Rocić B, Vucić M, Knezević-Cuća J, Radica A, Pavlić-Renar I, Profozić V, Metelko Z. Total plasma antioxidants in firstdegree relatives of patients with insulin-dependent diabetes. Exp Clin Endocrinol Diabetes 1997; 105: 213-7. http://dx.doi.org/10.1055/s-0029-1211754

[110] Santini SA, Marra G, Giardina B, et al. Defective plasma antioxidant defenses and enhanced susceptibility to lipid peroxidation in uncomplicated IDDM. Diabetes 1997; 46: 1853-8.

http://dx.doi.org/10.2337/diabetes.46.11.1853

[111] Cimbaljević B, Vasilijević A, Cimbaljević S, et al. Interrelationship of antioxidative status, lipid peroxidation, and lipid profile in insulin-dependent and non-insulindependent diabetic patients. Can J Physiol Pharmacol 2007; 85: 997-1003.

http://dx.doi.org/10.1139/Y07-088

[112] Newsholme P, Haber EP, Hirabara SM, et al. Diabetes associated cell stress and dysfunction: role of mitochondria and non-mitochondrial ROS production and activity. J Physiol 2007; 583: 9-24.

http://dx.doi.org/10.1113/jphysiol.2007.135871

[113] Martens GA, Vervoort A, Van de Casteele M, et al. Specificity in beta cell expression of L-3-hydroxyacyl-CoA dehydrogenase, short chain, and potential role in downregulating insulin release. J Biol Chem 2007; 282:21134-44. http://dx.doi.org/10.1074/jbc.M700083200

[114] Jun T, Sakinis A, Wennmalm A. The insulin secretory response to intravenous glucose in the rat is independent of NO formation. Acta Physiol Scand 1995; 155: 61-5. http://dx.doi.org/10.1111/j.1748-1716.1995.tb09948.x

[115] Patel AG, Toyama MT, Nguyen TN, et al. Role of nitric oxide in the relationship of pancreatic blood flow and exocrine secretion in cats. Gastroenterology 1995; 108: 1215-20. http://dx.doi.org/10.1016/0016-5085(95)90222-8

[116] Bult H, Boeckxstaens GE, Pelckmans PA, Jordaens FH, Van Maercke YM, Herman AG. Nitric oxide as an inhibitory nonadrenergic non-cholinergic neurotransmitter. Nature 1990; 345: 346-7. http://dx.doi.org/10.1038/345346a0

[117] Yago MD, Mañas M, Ember Z, Singh J. Nitric oxide and the pancreas: morphological base and role in the control of the exocrine pancreatic secretion. Mol Cell Biochem 2001; 219 : 107-20.

http://dx.doi.org/10.1023/A:1010834611480

[118] DiMagno MJ, Hao Y, Tsunoda Y, Williams JA, Owyang C. Secretagogue-stimulated pancreatic secretion is differentially regulated by constitutive NOS isoforms in mice. Am J Physiol Gastrointest Liver Physiol 2004; 286: 428-36. http://dx.doi.org/10.1152/ajpgi.00368.2003

[119] Hammarstedt A, Graham TE, Kahn BB. Adipose tissue dysregulation and reduced insulin sensitivity in non-obese individuals with enlarged abdominal adipose cells. Diabetol Metab Syndr 2012; 4: 42.

http://dx.doi.org/10.1186/1758-5996-4-42 
[120] Fu WJ, Haynes TE, Kohli R, et al. Dietary L-arginine supplementation reduces fat mass in Zucker diabetic fatty rats. J Nutr 2005; 135: 714-21.

[121] Wu G, Lee MJ, Fried SK. The arginine-NO pathway modulates lipolysis in adipose tissues of obese human subjects. FASAB J 2007; 21: A1052.

[122] Jobgen W, Fu WJ, Gao H, et al. High fat feeding and dietary L-arginine supplementation differentially regulate gene expression in rat white adipose tissue. Amino Acids 2009; 37: 187-98.

http://dx.doi.org/10.1007/s00726-009-0246-7

[123] Lucotti $P$, Setola E, Monti LD, et al. Beneficial effects of a long-term oral L-arginine treatment added to a hypocaloric diet and exercise training program in obese, insulin-resistant type 2 diabetic patients. Am J Physiol Endocrinol Metab 2006; 291: 906-12.

http://dx.doi.org/10.1152/ajpendo.00002.2006

[124] Janković A, Buzadžić B, Korać A, Petrović V, Vasilijević A, Korać $B$. Antioxidative defense organization in retroperitoneal white adipose tissue during acclimation to cold-The involvement of L-arginine/NO pathway. J Therm Biol 2009; 34: 358-65.

http://dx.doi.org/10.1016/j.jtherbio.2009.06.007

[125] Monti LD, Galluccio E, Lucotti P, et al. Beneficial role of Larginine in cardiac matrix remodelling in insulin resistant rats. Eur J Clin Invest 2008; 38: 849-56.

http://dx.doi.org/10.1111/j.1365-2362.2008.02027.x

[126] Saleh Al, Abdel Maksoud SM, El-Maraghy SA, Gad MZ. Protective effect of L-arginine in experimentally induced myocardial ischemia: comparison with aspirin. J Cardiovasc Pharmacol Ther 2011; 16: 53-62. http://dx.doi.org/10.1177/1074248410378506

[127] Miguez I, Marino G, Rodriguez B, Taboada C. Effects of dietary L-arginine supplementation on serum lipids and intestinal enzyme activities in diabetic rats. J Physiol Biochem 2004; 60: 31-7. http://dx.doi.org/10.1007/BF03168218

[128] Jobgen WS, Fried SK, Fu WJ, Meininger CJ, Wu G. Regulatory role for the arginine-nitric oxide pathway in metabolism of energy substrates. J Nutr Biochem 2006; 17: 571-88.

http://dx.doi.org/10.1016/j.jnutbio.2005.12.001

[129] McKnight JR, Satterfield MC, Jobgen WS, et al. Beneficial effects of L-arginine on reducing obesity: potential mechanisms and important implications for human health. Amino Acids 2010; 39: 349-57.

http://dx.doi.org/10.1007/s00726-010-0598-Z

[130] Tan B, Yin Y, Liu Z, et al. Dietary L-arginine supplementation differentially regulates expression of lipid-metabolic genes in porcine adipose tissue and skeletal muscle. J Nutr Biochem 2011; 22: 441-5.

http://dx.doi.org/10.1016/j.jnutbio.2010.03.012

[131] Chessler SD, Fujimoto WY, Shofer JB, Boyko EJ, Weigle DS. Increased plasma leptin levels are associated with fat accumulation in Japanese Americans. Diabetes 1998; 47: 239-43.

http://dx.doi.org/10.2337/diabetes.47.2.239

[132] Stingl H, Raffesberg W, Nowotny P, WaldhäusI W, Roden M. Reduction of plasma leptin concentrations by arginine but not lipid infusion in humans. Obes Res 2002; 10: 1111-9.

http://dx.doi.org/10.1038/oby.2002.151

[133] Hirosumi J, Tuncman G, Chang L, et al. A central role for JNK in obesity and insulin resistance. Nature (London) 2002; 420: 333-6.

http://dx.doi.org/10.1038/nature01137

[134] Silha JV, Krsek M, Skrha JV, Sucharda P, Nyomba BL, Murphy LJ. Plasma resistin, adiponectin and leptin levels in lean and obese subjects: correlations with insulin resistance. Eur J Endocrinol 2003; 149: 331-5. http://dx.doi.org/10.1530/eje.0.1490331
[135] Smith SR, Bai F, Charbonneau C, Janderova L, Argyropoulos G. A promoter genotype and oxidative stress potentially link resistin to human insulin resistance. Diabetes 2003; 52: 1611-8.

http://dx.doi.org/10.2337/diabetes.52.7.1611

[136] Cannon B, Nedergaard J. Brown adipose tissue: function and physiological significance. Physiol Rev 2004; 84: 277-359. http://dx.doi.org/10.1152/physrev.00015.2003

[137] Cypess AM, Lehman S, Williams G, et al. Identification and importance of brown adipose tissue in adult humans. $N$ Engl J Med 2009; 360: 1509-17. http://dx.doi.org/10.1056/NEJMoa0810780

[138] Virtanen KA, Lidell ME, Orava J, et al. Functional brown adipose tissue in healthy adults. N Engl $\mathrm{J}$ Med 2009; 360: 1518-25. http://dx.doi.org/10.1056/NEJMoa0808949

[139] van Marken Lichtenbelt WD, Vanhommerig JW, Smulders $\mathrm{NM}$, et al. Cold-activated brown adipose tissue in healthy men. N Engl J Med 2009; 360: 1500-8.

http://dx.doi.org/10.1056/NEJMoa0808718

[140] Vasilijević A, Vojčić Lj, Dinulović I, et al. Expression pattern of thermogenesis-related factors in interscapular brown adipose tissue of alloxan-treated rats: beneficial effect of $L$ arginine. Nitric Oxide 2010; 23: 42-50.

http://dx.doi.org/10.1016/j.niox.2010.04.001

[141] Jobgen W, Meininger CJ, Jobgen SC, et al. Dietary Larginine supplementation reduces white fat gain and enhances skeletal muscle and brown fat masses in dietinduced obese rats. J Nutr 2009; 139: 230-7. http://dx.doi.org/10.3945/in.108.096362

[142] Petrović $V$, Korać A, Buzadžić B, Korać B. The effects of Larginine and L-NAME supplementation on redox-regulation and thermogenesis in interscapular brown adipose tissue. $J$ Exp Biol 2005; 208: 4263-71. http://dx.doi.org/10.1242/jeb.01895

[143] Korać A, Buzadžić B, Petrović V, et al. The role of nitric oxide in remodeling of capillary network in rat interscapular brown adipose tissue after long-term cold acclimation. Histol Histopathol 2008; 23: 441-50.

[144] Korać A, Buzadžić B, Petrović V, Vasilijević A, Janković A, Korać $B$. Leptin immunoexpression and innervation in rat interscapular brown adipose tissue of cold-acclimated rats: the effects of L-arginine and L-NAME. Folia Histochem Cytobiol 2008; 46: 103-9. http://dx.doi.org/10.2478/v10042-008-0015-6

[145] Petrović V, Korać A, Buzadžić B, et al. Nitric oxide regulates mitochondrial re-modelling in interscapular brown adipose tissue: ultrastructural and morphometric-stereologic studies. J Microsc 2008; 232: 542-8.

http://dx.doi.org/10.1111/j.1365-2818.2008.02132.x

[146] Petrović V, Buzadžić B, Korać A, Vasilijević A, Janković A, Korać B. NO modulates the molecular basis of rat interscapular brown adipose tissue thermogenesis. Comp Biochem Physiol C Toxicol Pharmacol 2010; 152: 147-59. http://dx.doi.org/10.1016/j.cbpc.2010.03.008

[147] Vučetić $M$, Otašević $V$, Korać $A$, et al. Interscapular brown adipose tissue metabolic reprogramming during cold acclimation: Interplay of HIF-1a and AMPKa. Biochim Biophys Acta 2011; 1810: 1252-61.

[148] Khedara A, Goto T, Morishima M, Kayashita J, Kato N. Elevated body fat in rats by the dietary nitric oxide synthase inhibitor, L-N omega nitroarginine. Biosci Biotechnol Biochem 1999; 63: 698-702.

http://dx.doi.org/10.1271/bbb.63.698

[149] Piatti PM, Monti LD, Valsecchi G, et al. Long-term oral Larginine administration improves peripheral and hepatic insulin sensitivity in type 2 diabetic patients. Diabetes Care 2001; 24: 875-80.

http://dx.doi.org/10.2337/diacare.24.5.875 
[150] Bogdanski P, Suliburska J, Grabanska K, et al. Effect of 3month L-arginine supplementation on insulin resistance and tumor necrosis factor activity in patients with visceral obesity. Eur Rev Med Pharmacol Sci 2012; 16: 816-23.

[151] Baron AD, Steinberg H, Brechtel G, Johnson A. Skeletal muscle blood flow independently modulates insulin-mediated glucose uptake. Am J Physiol 1994; 266: 248-53.

[152] Baron AD, Steinberg $H O$, Chaker $H$, Leaming R, Johnson A, Brechtel G. Insulin-mediated skeletal muscle vasodilation contributes to both insulin sensitivity and responsiveness in lean humans. J Clin Invest 1995; 96: 786-92. http://dx.doi.org/10.1172/JCl118124

[153] Petrie JR, Ueda S, Webb DJ, Elliott HL, Connell JM. Endothelial nitric oxide production and insulin sensitivity. A physiological link with implications for pathogenesis of cardiovascular disease. Circulation 1996; 93: 1331-3. http://dx.doi.org/10.1161/01.CIR.93.7.1331

[154] Kobzik L, Stringer B, Balligand JL, Reid MB, Stamler JS. Endothelial type nitric oxide synthase in skeletal muscle fibers: mitochondrial relationships. Biochem Biophys Res Commun 1995; 211: 375-81.

http://dx.doi.org/10.1006/bbrc.1995.1824

[155] Bates TE, Loesch A, Burnstock G, Clark JB. Mitochondrial nitric oxide synthase: a ubiquitous regulator of oxidative phosphorylation? Biochem Biophys Res Comm 1996; 218 : 40-4. http://dx.doi.org/10.1006/bbrc. 1996.0008

[156] Ribiere C, Jaubert AM, Gaudiot N, et al. White adipose tissue nitric oxide synthase: a potential source for NO production. Biochem Biophys Res Commun 1996; 222: 706-12. http://dx.doi.org/10.1006/bbrc.1996.0824

[157] Young ME, Leighton B. Evidence for altered sensitivity of the nitric oxide/cGMP signalling cascade in insulin-resistant skeletal muscle. Biochem J 1998; 329: 73-9.

[158] Balon TW, Nadler JL. Evidence that nitric oxide increases glucose transport in skeletal muscle. J Appl Physiol 1997; 82: 359-63.

[159] Roy D, Perreault M, Marette A. Insulin stimulation of glucose uptake in skeletal muscles and adipose tissues in vivo is NO dependent. Am J Physiol 1998; 274: 692-9.

[160] Marliss EB, Chevalier S, Gougeon R, et al. Elevations of plasma methylarginines in obesity and ageing are related to insulin sensitivity and rates of protein turnover. Diabetologia 2006; 49: 351-9.

http://dx.doi.org/10.1007/s00125-005-0066-6

[161] Higaki Y, Hirshman MF, Fujii N, Goodyear LJ. Nitric oxide increases glucose uptake through a mechanism that is distinct from the insulin and contraction pathways in rat skeletal muscle. Diabetes 2001; 50: 241-7. http://dx.doi.org/10.2337/diabetes.50.2.241

[162] Tanaka T, Nakatani K, Morioka K, et al. Nitric oxide stimulates glucose transport through insulin-independent GLUT4 translocation in 3T3-L1 adipocytes. Eur J Endocrinol 2003; 149: 61-7. http://dx.doi.org/10.1530/eje.0.1490061

[163] Douen AG, Ramlal T, Rastogi S, et al. Exercise induces recruitment of the "insulin-responsive glucose transporter". Evidence for distinct intracellular insulin- and exerciserecruitable transporter pools in skeletal muscle. J Biol Chem 1990; 265: 13427-30.

[164] Coderre L, Kandror KV, Vallega G, Pilch PF. Identification and characterization of an exercise-sensitive pool of glucose transporters in skeletal muscle. J Biol Chem 1995; 270: 27584-8.

http://dx.doi.org/10.1074/jbc.270.46.27584

[165] McConell GK, Huynh NN, Lee-Young RS, Canny BJ, Wadley GD. L-Arginine infusion increases glucose clearance during prolonged exercise in humans. Am $\mathrm{J}$ Physiol Endocrinol Metab 2006; 290: 60-6.

http://dx.doi.org/10.1152/ajpendo.00263.2005

[166] Young ME, Radda GK, Leighton B. Nitric oxide stimulates glucose transport and metabolism in rat skeletal muscle in vitro. Biochem J 1997; 322: 223-8.

[167] Young ME, Leighton B. Fuel oxidation in skeletal muscle is increased by nitric oxide/cGMP-evidence for involvement of cGMP-dependent protein kinase. FEBS Lett 1998; 424: 7983.

http://dx.doi.org/10.1016/S0014-5793(98)00143-4

[168] Salil G, Nithya R, Nevin KG, Rajamohan T. Dietary coconut kernel protein beneficially modulates NFKB and RAGE expression in streptozotocin induced diabetes in rats. J Food Sci Technol 2012; http://dx.doi.org/10.1007/s13197-012-0729-5

[169] Monti LD, Valsecchi G, Costa S, et al. Effects of endothelin-1 and nitric oxide on glucokinase activity in isolated rat hepatocytes. Metabolism 2000; 49: 73-80.

http://dx.doi.org/10.1016/S0026-0495(00)90763-7

[170] Long YC, Zierath JR. AMP-activated protein kinase signaling in metabolic regulation. J Clin Invest 2006; 116: 1776-83. http://dx.doi.org/10.1172/JCl29044

[171] Merrill GF, Kurth EJ, Hardie DG, Winder WW. AICA riboside increases AMP-activated protein kinase, fatty acid oxidation, and glucose uptake in rat muscle. Am J Physiol 1997; 273 1107-12.

[172] Hayashi T, Hirshman MF, Kurth EJ, Winder WW, Goodyear LJ. Evidence for 5' AMP-activated protein kinase mediation of the effect of muscle contraction on glucose transport. Diabetes 1998; 47: 1369-73. http://dx.doi.org/10.2337/diabetes.47.8.1369

[173] Kurth-Kraczek EJ, Hirshman MF, Goodyear LJ, Winder WW. 5' AMP-activated protein kinase activation causes GLUT4 translocation in skeletal muscle. Diabetes 1999; 48: 1667-71. http://dx.doi.org/10.2337/diabetes.48.8.1667

[174] Zheng D, MacLean PS, Pohnert SC, et al. Regulation of muscle GLUT-4 transcription by AMP-activated protein kinase. J Appl Physiol 2001; 91: 1073-83.

[175] de Castro Barbosa T, Jiang LQ, Zierath JR, Nunes MT. LArginine enhances glucose and lipid metabolism in rat L6 myotubes via the NO/ c-GMP pathway. Metabolism 2012; http://dx.doi.org/10.1016/j.metabol.2012.06.011

[176] Winder WW, Wilson HA, Hardie DG, et al. Phosphorylation of rat muscle acetyl-CoA carboxylase by AMP-activated protein kinase and protein kinase A. J Appl Physiol 1997; 82: 21925.

[177] Lochhead PA, Salt IP, Walker KS, Hardie DG, Sutherland C. 5-aminoimidazole-4-carboxamide riboside mimics the effects of insulin on the expression of the 2 key gluconeogenic genes PEPCK and glucose-6-phosphatase. Diabetes 2000; 49: 896-903. http://dx.doi.org/10.2337/diabetes.49.6.896

[178] Zhou G, Myers R, Li Y, et al. Role of AMP-activated protein kinase in mechanism of metformin action. J Clin Invest 2001; 108: 1167-74.

[179] Zou MH, Kirkpatrick SS, Davis BJ, et al. Activation of the AMP-activated protein kinase by the anti-diabetic drug metformin in vivo. Role of mitochondrial reactive nitrogen species. J Biol Chem 2004; 279: 43940-51. http://dx.doi.org/10.1074/jbc.M404421200

[180] Linden KC, Wadley GD, Garnham AP, McConell GK. Effect of $L$-arginine infusion on glucose disposal during exercise in humans. Med Sci Sports Exerc 2011; 43: 1626-34. http://dx.doi.org/10.1249/MSS.0b013e318212a317

[181] Jobgen WJ. PhD Dissertation. Texas A\&M University; 2007. Dietary L-arginine Supplementation Reduces Fat Mass in Diet-Induced Obese Rats. 
[182] Newsholme P, Keane D, Welters HJ, Morgan NG. Life and death decisions of the pancreatic beta-cell: the role of fatty acids. Clin Sci (Lond) 2007; 112: 27-42. http://dx.doi.org/10.1042/CS20060115
[183] Nyblom HK, Sargsyan E, Bergsten P. AMP-activated protein kinase agonist dose dependently improves function and reduces apoptosis in glucotoxic beta-cells without changing triglyceride levels. J Mol Endocrinol 2008; 41: 187-94. http://dx.doi.org/10.1677/JME-08-0006 